DOI: $10.14720 /$ aas.2016.107.1.19

Agrovoc descriptors: transgenic plants; vaccines; infectious diseases; recombinant proteins; antibodies; risk assessment; risk analysis

Agris category code: F30

\title{
Production of vaccines for treatment of infectious diseases by transgenic plants
}

\author{
Kristina LEDL ${ }^{1}$, Zlata LUTHAR ${ }^{2 *}$
}

Received February 16, 2016; accepted March 18, 2016.

Delo je prispelo 16. februarja 2016, sprejeto 18. marca 2016.

\begin{abstract}
Since the first pathogen antigen was expressed in transgenic plants with the aim of producing edible vaccine in early $1990 \mathrm{~s}$, transgenic plants have become a well-established expression system for production of alternative vaccines against various human and animal infectious diseases. The main focus of plant expression systems in the last five years has been on improving expression of well-studied antigens such as porcine reproductive and respiratory syndrome (PRRSV), bovine viral diarrhea disease virus (BVDV), footh and mouth disease virus (FMDV), hepatitis $\mathrm{B}$ surface antigen (HBsAg), rabies $\mathrm{G}$ protein, rotavirus, Newcastle disease virus (NDV), Norwalk virus capsid protein (NVCP), avian influenza virus $\mathrm{H} 5 \mathrm{~N} 1$, Escherichia coli heat-labile enterotoxin subunit B (LT-B), cholera toxin B (CT-B), human immunodeficiency virus (HIV), artherosclerosis, ebola and anthrax. Significant increases in expression have been obtained using improved expression vectors, different plant species and transformation methods.
\end{abstract}

Key words: transgenic plants; vaccine production; recombinant proteins; antibodies; infectious diseases; risk assessment

\section{IZVLEČEK}

\section{ZDRAVLJENJE NALEZLJIVIH BOLEZNI S CEPIVI PRIDOBLJENIMI S TRANSGENIMI RASTLINAMI}

Pridobivanje aktivnih sestavin za cepiva $\mathrm{s}$ transgenimi rastlinami se je začelo $\mathrm{v}$ devetdesetih letih prejšnjega stoletja. Od takrat se transgene rastline uveljavljajo kot alternativni ekspresijski sistem za sintezo aktivnih komponent za cepiva proti številnim humanim in živalskim nalezljivim boleznim. V zadnjih petih letih je bil glavni poudarek razvoja namenjen optimizaciji rastlinskih ekspresijskih sistemov za dobro proučene antigene, kot so virus prašičjega respiratornega in reproduktivnega sindroma, virus goveje virusne diareje, virus parkljevke, površinski antigen hepatitisa $B, G$ protein virusa stekline, rotavirus, virus atipične kokošje kuge, plaščni protein Norwalk virusa, sev ptičje gripe $\mathrm{H} 5 \mathrm{~N} 1$, temperaturno nestabilna B podenota enterotoksina Escherischia coli, kolera toksin B, HIV, arterioskleroza, ebola in antraks. Uporaba optimiziranih transformacijskih metod in ekspresijskih vektorjev v kombinaciji s primerno izbrano rastlinsko vrsto je $\mathrm{v}$ večini naštetih primerov vodila do opaznega izboljšanja sinteze posameznih učinkovin.

Ključne besede: transgene rastline; pridobivanje cepiv; rekombinantni proteini; protitelesa; nalezljive bolezni; ocena tveganja

\section{INTRODUCTION}

Vaccination is the most effective known way of preventing outbreaks and spreading of viral and bacterial infections. Traditional vaccines contained attenuated or inactivated pathogens, however the development of molecular biology, genetics, medicine and biotechnology in past decades resulted in many novel vaccine types and production systems. During the last 20 years, transgenic plants have started gaining importance as a potential alternative host system for expressing high amounts of safe, cheap, effective easily applicable oral vaccines. Some of the main

1 Department of Agronomy, Biotechnical Faculty, University of Ljubljana, Jamnikarjeva 101, SI-1000 Ljubljana, study programe in biotechnology, e-mail: kristinaleedl@gmail.com

2 Department of Agronomy, Biotechnical Faculty, University of Ljubljana, Jamnikarjeva 101, SI-1000 Ljubljana, * corresponding author: e-mail: zlata.luthar@bf.uni-lj.si 
advantages of plant-made vaccines are the absence of pathogens commonly found in mammalian, bacterial and yeast production systems, easier storage and transport and ability of inducing both systemic and mucosal immune response thus granting bigger protection against pathogen challenge. The main focus of the initial research as well as the recent development has been expression of various antigens belonging to agents of viral and bacterial infectious diseases of humans, animals or both. Most of the expressed antigens have been successfully evaluated in animal and human models. Besides that quite a lot of research has been done in the field of expressing antigens related with autoimmune diseases, such as artherosclerosis, diabetes type 1, rheumatoid arthritis and multiple sclerosis. The following article aims to cover some of the recent advances in expressing pathogen antigens in transgenic plants, transformation methods and vectors.

\section{VIRAL VACCINES}

\subsection{Porcine reproductive and respiratory syndrome}

Porcine reproductive and respiratory syndrome (PRRS) is a highly transmissible disease of sows and piglets, which was first reported in the US in 1987 and in Europe in 1990 (Chen and Liu, 2011) and has since spread to become one of the most devastating infectious diseases of swine industry nowadays, causing major economic losses in swine herds worldwide. Its cause is the porcine reproductive and respiratory syndrome virus (PRRSV). Currently, modified-live and inactivated (killed-virus) PRRSV vaccines are being used, but due to safety risks (revertion back to virulence) and inability of protecting against heterologous PRRSV infections of the first ones and weak effectiveness of the second ones, there's a great demand for development of novel vaccines (Chia et al., 2010; Hu et al., 2012; Renukaradhya et al., 2015). Porcine reproductive and respiratory syndrome GP5 glycoprotein 5 (PRRSV GP5), one of the main target antigens, was first expressed in transgenic tobacco plants in 2010, with expression levels reaching app. $0.011 \%$ total soluble protein (TSP), despite the addition of endoplasmic reticulum (ER) retention signal KDEL and cauliflower mosaic virus (CaMV 35S) promoter. However, oral immunization with fresh leaf tissue triggered both PRRSV-specific humoral and cellular immune response (saliva IgA and systemic IgG) in mice (Chia et al., 2010). With the aim of increasing the expression level of GP5, Chia et al. (2011) later fused GP5 with Escherichia coli heatlabile toxin subunit B (LT-B) and additional endoplasmic reticulum targeting HDEL sequence, expressed it in Nicotiana tabacum under the control of ubiquitin promoter 1 (UBQ1). The immunogenicity of the obtained fusion protein was evaluated in orally immunized pigs. Expression level in this case was $0.0155 \%$ TSP. LT-B-GP5 fusion protein was able to induce GP5-specific PRRSV mucosal and systemic immunity after intranasal PRRSV challenge at slightly higher rate than GP5 alone. GP5 protein was also successfully expressed in transgenic potato tubers (yields $0.8-$ $1.2 \mu \mathrm{g} / \mathrm{g}$ ) and leaves (yields $2.5-4.7 \mu \mathrm{g} / \mathrm{g}$ ) (Chen and Liu, 2011) and induced the production of PRRSV-specific intestine $\operatorname{IgA}$ and serum $\operatorname{IgG}$ when applied orally as crude tuber extracts. Chan et al. (2013) expressed GP5 in transgenic banana leaf tissue, driven by CaMV 35 S promoter with 3'flanking Mh-UBQ1 matrix-associated regions (MARs) and HDEL, with yields $0.021-0.037 \%$ of TSP $(154-257 \mathrm{ng} / \mathrm{g}$ of fresh banana leaves). That is 2-3 times higher than in transgenic tobacco $(0.018-0.0155 \%$ of TSP) (Chan et al, 2013), while the levels of neutralizing antibody (NA) titres in orally immunized pigs 3 weeks post infection (WPI) were similar to those obtained in pigs orally immunized with GP5 from transgenic tobacco- 1:4 - 1:16 (Chia et al., 2011). Immunized pigs developed PRRSV-specific humoral and cellular immune response. $\mathrm{Hu}$ et al. (2012) expressed PRRSV $M$ protein driven by UBQ promoter in transgenic corn calli and obtained strong consecutive expression as well as induction of humoral, mucosal and cellular immune responses in orally immunized mice $(30 \mathrm{mg}$ of dried corn powder with adjuvants). The highest $\mathrm{M}$ protein yield was $5.1 \mu \mathrm{g} / \mathrm{g}$ of fresh and $86 \mu \mathrm{g} / \mathrm{g}$ of lyophilized callus. Recently, Piron et al. (2014) expressed a whole Eu-prototype LV PRRSV antigenic set in seeds of Arabidopsis thaliana, with or without transmembrane domains, with added affinity tags or stabilizing protein domains- Fc IgG 
chain or green fluorescent protein (GFP), regulatory sequences of Phaseolus vulgaris, Nterminal fusion of $A$. thaliana $2 \mathrm{~S}$ albumin seed storage signal peptide and C-terminal ER-retention signal HDEL. Even though all antigens were found to be correctly N-glycosylated, further studies will be needed to determine whether or not they have really been processed in ER. Fusion of stabilizing protein domains to truncated GP3- GP5-Tm positively affected their accumulation, the most of all GFP fusion, its addition to truncated GP3 and GP4 resulted in accumulation of $2.74 \%$ and $2.36 \%$, respectively, which is way above the lowest economically feasible level. Full-length Gp4 and GP5 accumulated only at levels 0.08 and $0.1 \%$ of TSP, respectively, while fusion of stabilizing protein domain increased it up to $2.36 \%$ of TSP for GP3 and GP4. Fusion of pFc and $\mathrm{mFc} 2 \mathrm{a}$ to truncated antigens increased the accumulation (from $0.05 \%$ to $0.67 \%$ and $1.59 \%$, respectively) while addition of $\mathrm{pFc}$ to GP5 decreased the accumulation (from $0.10 \%$ to $0.01 \%$ of TSP). Addition of $\mathrm{Fc}$ domain also allowed for single-step protein-A affinity chromatography with recovery of about $60 \%$ (Piron et al., 2014). All 3 tested antigens (GFPfused truncated GP3, mFc2a-fused truncated $\mathrm{Gp} 4$ and normal-size-mFc2a-fused GP4) induced high GP4-Tm-specific Ab titres, only GP4-Tm:mFc2a elicited NA. In pigs, there were no NA detected when immunized with pFC-fused truncated GP3, GP4 and GP5 and 5 weeks after the second immunization only 1 pig had high serum Ab titres. Recently, Uribe-Campero et al. (2015) coexpressed PRRSV GP5, $\mathrm{M}$ and $\mathrm{N}$ protein in Nicotiana silvestris leaf tissue. Agrobacteriummediated transformation was performed. The proteins assembled in virus-like particles (VLPs) of expected size $(15,19$ and $25 \mathrm{kDa})$. When applied to mice by intraperitoneal immunization, the VLPs were shown to be immunogenic in mice.

\subsection{Bovine viral diarrhea virus}

Bovine viral diarrhea disease is an important cause of economic loss in global bovine herds, caused by bovine viral diarrhea virus (BVDV). Currently, inactivated vaccines are being used, however the E2 protein has been deemed the main target in developing novel subunit vaccines. Dus Santos and Widgorovitz (2005) produced transgenic alfalfa plants containing the gene for BVDV E2 glycoprotein under the control of CaMV $35 \mathrm{~S}$ promoter with TEV and KDEL signal sequences, transported into alfalfa in recombinant binary pBI121-TEV-Stag-E2-His-SEKDEL vector by $A$. tumefaciens transformation method. The approximate concentration of the recombinant protein expressed in 2 highest yielding plants was estimated between 0.05 and $0.5 \mathrm{mg} / \mathrm{g}$ TSP. In 2012, Nelson et al. expressed a truncated version of BVDV glycoprotein E2 (tE2), lacking the transmembrane domain with additional ERretention signal KDEL, 2S2 A. thaliana plant secretory pathway signal, the Kozak sequence and a hexa-histidine tag, in transgenic tobacco plants (N. tabacum). pK7GW2 Agrobacterium binary vector was transported into leaf tissue by Agrobacterium-mediated transformation. The protein accumulated at levels app. $1.3 \%$ TSP $(20 \mu \mathrm{g} / \mathrm{g})$ which is suitable for mass scale production and elicited an immune response comparable to that of commercial whole virus vaccine in subcutaneously immunized guinea pigs either with oily or aqueous adjuvant (86\% seroconversion with anti-BVDV Ab titres $>0.6$ and $75 \%$ seroconversion, respectively). When administered with aqueous adjuvant, recombinant tE2 elicited NA titers equal or higher than titers elicited by conventional vaccine. A year later, Aguirreburualde et al. (2013) expressed a truncated E2 protein, fused to APCH gene, under the control of Cassava striate mosaic virus (CsMV) promoter in recombinant binary plasmid pCs-APCHtE2, transformed into alfalfa petioles by Agrobacterium-mediated co-cultivation. APCHtE2 was stably expressed in alfalfa leaves with level of $0.1 \%$ of TSP, which is a significant increase as compared with the previous work. The final yield of $3.45 \mu \mathrm{g} / \mathrm{ml}$ of $\mathrm{Ag}$ permitted the formulation of an effective vaccine for cattle immunization. Parentally immunized guinea pigs developed NA titres $>2.4$ and immunized cattle developed NA titres $>2$ at the time of vaccination (t60). After challenge, 6 out of 8 bovines inoculated with $3 \mu \mathrm{g}$ of alfalfa-produced APCHtE2 showed complete virological protection after virus challenge. Aguirreburualde et al. (2013) suspect the APCH signal sequence directs the protein secretion to the apoplast but further investigations of this are needed. Average expression level of APCH-tE2 was $3 \mu \mathrm{g} / \mathrm{ml}$ of extract. From $50 \mathrm{~g}$ of transgene leaf tissue $80 \mu \mathrm{g}$ of APCH-tE2 can be produced after processing, 
which suffices for 27 doses of vaccine for cattle (1 dose $=3 \mu \mathrm{g}$ of APCH-tE2).

\subsection{Foot and mouth disease virus}

Foot and mouth disease is a highly contagious disease of cloven-foot animals and a major cause of economical loss in livestock. There are 7 different serotypes of the foot and mouth disease virus (FMDV), infection with any serotype doesn't confer immunity against the others (Zhang et al., 2011). Currently used attenuated and conventionally inactivated vaccines are not completely safe neither effective so there is a great focus in developing novel vaccines. Experimental vaccines containing FMDV antigens from transgenic plants have been reported safer than conventional vaccines; they are also cheaper and more effective. The first experimental plant-made FMDV vaccine was produced by Carillo et al. (1998), FMDV viral protein 1 (VP1) from transgenic $A$. thaliana plants. Later on there was a lot of production of complete or fractionated VP1 with the aim of producing an effective, highly immunogenic, easy to use and cheap plant-made FMDV Ag vaccine. VP1 epitope 135 - 160 has been expressed in transgenic alfalfa (Widgorovitz et al., 1999; Dus Santos et al., 2002; Dus Santos and Widgorovitz, 2005), A. thaliana (Carillo et al., 1998; Dus Santos and Widgorovitz, 2005) and potato (Dus Santos and Widgorovitz, 2005), structural polyproteins- precursors for empty FMDV capsids, $\mathrm{P} 1-3 \mathrm{C}$ and $\mathrm{P} 1-2 \mathrm{~A} 3 \mathrm{C}$ have been expressed in transgenic alfalfa (Dus Santos and Widgorovitz, 2005; Dus Santos et al., 2005) and tomato (Pan et al., 2008), respectively, and two serotypes of the structural FMDV VP1 protein, Oand Asia 1-type have been expressed in transgenic forage maize (Zhang et al., 2011). When used as an experimental vaccine for either oral immunization by feeding fresh plant tissue or parental, intraperitoneal vaccination with transgenic plant extracts VP1 epitope induced FMDV-specific systemic immune response and gave protection against FMDV infection after experimental viral FMDV challenge (Carillo et al., 1998; Widgorovitz et al., 1999; Dus Santos et al., 2002), recombinant protein yields however were low, between 0.01 and $0.2 \mathrm{mg} / \mathrm{g}$ in transgenic alfalfa (Dus Santos and Widgorovitz, 2005), the highest level of expression of FMDV VP1 135-160 epitope expressed in alfalfa being $0.5-1 \mathrm{mg} / \mathrm{g}$ of TSP, which was 10 times higher than in the cases of Widgorovitz et al. (1999) and Carillo et al. (1998). No significant differences in transformation success, protein expression or immunogenicity were observed with regards of using different $A$. tumefaciens strains or host systems. Dus Santos and Wisgorovitz (2005) expressed FMDV VP1 P1-3C in transgenic alfalfa with expression level $0.01-0.2 \mathrm{mg} / \mathrm{g}$ of TSP when binary pRok plasmid and $A$. tumefaciens strain $\mathrm{C} 58 \mathrm{C} 1$ were used and with expression levels of $0.005-0.01 \mathrm{mg} / \mathrm{g}$ of TSP in another case, in both cases the obtained recombinant peptide induced strong $\mathrm{Ab}$ and NA response as well as complete virological protection in vaccinated mice. Pan et al. (2008) expressed P1-2A3C FMDV VP1 polyprotein in tomato, its expression was lower than that obtained in FMDV-infected animal cells despite the use of KDEL, Kozak sequence and 35S promoter; however the immunogenicity in intramuscularly immunized guinea pigs was still very high, with $\mathrm{Ab}$ titres 21 days after the third vaccination $0.8-2 \log 10$. A FMDV-specific memory cell response was generated as well. When Zhang et al. (2011) expressed FMDV serotypes $\mathrm{O}-$ and Asia 1-type in transgenic forage maize, 3 - 5 transgene copies of VP1 fusion protein were found inserted in genomes of transformed plants and the transgene was found to be passed on to offspring. Ag induced protective systemic immune response when fed to animals.

\subsection{Hepatitis B}

Hepatitis $\mathrm{B}$ is one of the most frequent contagious diseases. It is caused by a hepatitis B virus (HBV) and mainly damages liver, can lead to liver cirrhosis or hepatocellular carcinoma. HBV is a retrovirus, one of the smallest eukaryotic DNA viruses (Guan et al., 2013). Negative HBV strand has 4 ORFs, $C, P, S$ and $X$ gene encoding four major viral proteins: core $\mathrm{Ag}(\mathrm{HBcAg} / \mathrm{HBe} A g)$, HBV DNA polymerase (HBV DNA P), surface Ag (HBsAg) and X Ag (HBxAg), respectively (Guan et al., 2013). Since the first reported plant-made $\mathrm{HB} \mathrm{Ag}$ in $A$. tumefaciens strain LBA4404transformated tobacco by Mason et al. (1992) there has been a huge research on expressing major HBV viral proteins. Recombinant HBsAg has been expressed in lupine and lettuce (Kapusta et al., 1999), carrot suspension cells (Zhao et al., 2002), soybean (Smith et al., 2002), peanut (Chen et al., 2002), tomato (Ma et al., 2002; Carolina and 
Francisco, 2004; Wang and Li, 2008; Srinivas et al., 2008), cherry tomatillo (Gao et al., 2003; Guan et al., 2010), potato (Shulga et al., 2004), banana (Sunil-Kumar et al., 2005), apple core and leaves and tomato (Lou et al., 2005), NT-1 cells of tobacco (Sunil-Kumar et al, 2007) and lettuce (Kostrzak et al., 2011). Chen et al. (2002) reported a high level expression of HBsAg in peanut, obtained by Agrobacterium-mediated transformation, with the yield of $2.42 \mu \mathrm{g} \mathrm{HBsAg} / \mathrm{g}$ of fresh weight. Oral immunization was shown to have triggered anti-HBsAg response both in mice (Kapusta et al., 1999; Gao et al., 2003) and humans (Kapusta et al., 1999; Thanavala et al., 2005). Many of HBsAg expression systems are still undergoing the process of development and optimisation and new plant species are being tested as possible expression systems. The most recent experiments include cucumber (Unni and Soniya, 2010), sandalwood embryogenic cell suspension cultures (Shekhawat et al., 2010), maize (Hayden et al., 2012; Hayden et al., 2015; Shah et al., 2015) and lettuce (Pniewski et al., 2011), as well as the most recent progress in using potato as host system (Rukavtsova et al., 2015). Even though the first effective parental hepatitis B vaccine by yeast has been developed more than 20 years ago, the vaccine still isn't accessible, effective or is costprohibitive for a lot of world's population, especially for areas that need it the most. A big problem is also the storage of the vaccine as the adjuvanted purified $\mathrm{Ag}$ protein loses its immunogenicity when frozen, thawed or stored for a week at $45^{\circ} \mathrm{C}$ and in not thermostable (Shah et al., 2015). An oral, low-cost thermostable plantmade subunit vaccine could help overcome those problems. In 2011, Pniewski et al. expressed $\mathrm{HBsAg}$ in glufosinat-resistant transgenic lettuce to use as a prototype oral vaccine suitable for human immunization. Total HBsAg level in lyophilized tissue was $5 \mathrm{mg} / \mathrm{g}$, whereas the mean content of VLP-structuralized Ag was $11 \mu \mathrm{g} / \mathrm{g}$ and in tablets 5 or $2.3 \mu \mathrm{g} / \mathrm{g}$. Obtained vaccine consisted of 100 ng VLP-assembled Ag dosage, produced in transgenic lettuce and mice were orally immunized with lyophilized tissue without additional exogenous adjuvants. Two immunizations with 60day interval in between them resulted in both mucosal and peripheral humoral immune response against HBV, with titres above the nominal protective titres $(10 \mathrm{mIU} / \mathrm{ml})$. When converted into tablets and stored at room temperature, $\mathrm{HBsAg}$ content in lyophilized tissue was preserved for a year. Even though the lyophilisation reduced the HBsAg content for at least $90 \%$, the low dosage was still efficient. In 2010, Unni and Soniya expressed HBsAg in transgenic salad cucumber (Cucumis sativus cv. 'Swarnamukhi') plants as a part of trials to find new vaccine-producing plants suitable for raw human consumption. Using Agrobacterium-mediated transformation of $C$. sativus cotiledonary leaf section they produced transgenic C. sativus plants where $\mathrm{HBsAg}$ was successfully introduced and transcribed, with TDNA being present as single copy in some of the plants and as multiple copy in others, the transgene insertion pattern that is typical for Agrobacteriummediated transformation. Soluble proteins extracted from transformed plants showed a distinct band with molecular weight expected for the HBsAg gene. Protein expression levels were low, $0.006 \%$ of TSP (11.5-50 ng HBsAg/mg TSP), which was attributed to the absence of signal peptides for increasing protein accumulation, such as ER SEKDEL.

Besides using different plants, Shekhawat et al. (2010) expressed HBsAg in embryogenic cells suspension cultures of sandalwood (Santalum album). The team used Agrobacterium-mediated transformation technique, a C-terminal ER retention signal was added to hepatitis HBsAg gene and eight different growth medium aditives were tested with the aim of improving the HBsAg expression in transgenic cells. Maximum HBsAg expression in untreated transformed cells was $11.09 \mu \mathrm{g} / \mathrm{g}$ of fresh mass, while cells treated with $30 \mathrm{mM}$ trehalose reached $19.95 \mu \mathrm{g} / \mathrm{g}$, addition of $0.4 \%$ DMSO increased the expression by 1.36 fold, addition of gibberellic acid $(1.45 \mu \mathrm{M})$ by 1.48-fold, doubled concentration of $\mathrm{CaCl}_{2}$ in basic MS medium by 1.28 -fold and $0.001 \%$ Tween- 20 by 1.34 -fold. The biggest increase was obtained by addition of $54.88 \mathrm{mM}$ mannitol, with the increase of 1.7-fold. Due to bigger genetic stability of sandalwood as opposed to previously investigated soybean suspension cells (Smith et al., 2002) this study proved promising for further investigations of stable HBsAg expression in suspension cells of sandalwood.

The first report on successful expression and immunogenicity of bioencapsulated $\mathrm{HBsAg}$ was done in 2012 by Hayden et al., in maize, as the first 
commercially feasible oral subunit vaccine production for a major disease. HBsAg expression was driven by either polyubiquitin or the embryopreferred globulin 1 promoter and the effect of different signal sequences on the HBsAg accumulation in grains was tested. Accumulation of the HBsAg was the highest when driven by embryo-preferred globulin 1 promoter, with the highest yielding seed accumulating over $0.25 \%$ TSP. Germ enrichment and oil extraction from the seeds of plants produced by backcrossing of the 2 of the highest-yielding plants resulted in the total of $166 \mu \mathrm{g} \mathrm{HBsAg} / \mathrm{g}$ of dry maize material, 20-fold higher than in the highest previously reported case. Orally immunized mice elicited both strong mucosal and systemic immune response. As the next step towards maize-produced oral HBV vaccine, Hayden et al. (2015) recently carried out a study to determine whether or not oral delivery of maize-produced HBsAg doses establish long-termn immunologic memory in mice over a one year time period. Using the plant material from the previous study, Hayden et al. (2015) produced hybrid HBsAg seeds which were then processed into supercritical fluid $\mathrm{CO} 2$ extraction (SFE)-defatted wafers. Serum $\operatorname{IgG}$, serum $\operatorname{IgA}$ and fecal $\operatorname{IgA}$ responses were detected in mice intramuscularly immunized with commercial HBV vaccine Recombivax and fed with SFE-defatted wafers as well as in mice immunized with Recombivax and immunized with it afterwards. Storage and processing of wafers resulted in the final wafers containing $567 \mu \mathrm{g} \mathrm{HBsAg} / \mathrm{g}$, 3-fold more than in the beginning. Total serum $\mathrm{IgG}(\mathrm{mIU} / \mathrm{ml})$ showed clear evidence of immunologic memory over one year of oral and parenteral administration, geometric mean titres $(\mathrm{mIU} / \mathrm{ml})$ were high both in the case of HBsAg- and Recombivax-treated mice. Obtained HBsAg levels in seeds and resulting wafers are the highest reported $\mathrm{Ag}$ concentrations in plants to date. In the same year, the biochemical and biophysical characteristics of SFE-defatted maize-derived HBsAg were evaluated (Shah et al., 2015). Expression of HBsAg in plants has been recently enhanced by Hayden et al (2014) by fusing HBsAg to barley alpha amylase signal sequence (BAAS) and preferentially expressing it in the germ fraction of the hybrid maize seed, which resulted in HBsAg expression at a level of $1023 \mu \mathrm{g} / \mathrm{g}$, the highest reported HBsAg in plants up-to-date. Recently, Rukavtsova et al. (2015) tested the immunogenicity of marker-free transgenic potato-produced $\mathrm{HBsAg}$ in mice. The team developed a novel way of constructing a transgenic marker-free plant, inserting the HBsAg (driven by $35 \mathrm{~S}$ CaMV promoter) into the markerfree $\mathrm{pBM}$ vector and performed Agrobacteriummediated transformation. HBsAg level in the tubers of selected transgenic potato lines was up to $1 \mu \mathrm{g} / \mathrm{g}$ of wet weight. Existence of $\mathrm{HBsAg}$ multimers was confirmed by gel filtration. AntiHBsAg levels in mice fed with transgenic potato tubers began increasing on day $36-50$ after the $1^{\text {st }}$ feeding and by day 70 the $\mathrm{Ab}$ content was up to $170 \mathrm{mIU} / \mathrm{ml}$. After being experimentally challenged with recombinant yeast hepatitis $\mathrm{B}$ vaccine, that content rose up to $350 \mathrm{mIU} / \mathrm{ml}$ within 15-34 days after infection in orally immunized mice, staying high above the minimum protection level even 120 days after the start of the experiment (up to $100 \mathrm{mIU} / \mathrm{ml}$ ). When having been given additional 3 doses of HBsAg (320 days after the start of the experiment), the HBsAg Ab levels in serum of previously immunized mice increased up to $185 \mathrm{mIU} / \mathrm{ml}$, with animals preserving stable immunological memory of the infection. This was the first experiment using transgenic plants as a source of hepatitis B edible vaccine that lasted longer than 24-38 weeks, the way that was normal in similar experiments of other authors.

\subsection{Rabies}

Rabies is a globally widespread infectious disease affecting central nervous system in both animals and humans. It is caused by the Rabies virus. Despite the long research history it still remains incurable while vaccination is used as a mean of its prevention. Vaccines currently available on the market are obtained by propagating fixed Rabies virus strains in various animal cell cultures or chicken embryos (Starodubova et al., 2015). Despite being safe and efficacious, vaccines produced in such way can greatly vary between different producers, their efficiency can be significantly reduced by storage and transportation, are very costly, can sometimes cause adverse side effects and require 3 - 5 doses to provide sufficient immune protection (Rosales-Mendoza, 2015). In the last 20 years there has been a lot of research and progress in developing the fourth generation of rabies vaccines based on rabies glycoprotein $(G$ protein) (Starodubova et al., 2015). Neutralizing Abs against $G$ protein have been shown to be 
capable of preventing rabies infection. The pioneering work in expressing $G$ protein in transgenic plants was done in 1995 by McGarvey et al. by expressing an unmodified $\mathrm{G}$ protein gene under the control of the CaMV 35S promoter in Agrobacterium-transformated tomato leaves and fruits. Since then, $G$ protein has been expressed on its own in plants such as tobacco (Modelska et al., 1997; Yusibov et al., 1997; Ashraf et al., 2005,), spinach (Modelska et al., 1997), carrot (Anaya et al., 2009) and maize (Loza-Rubio et al., 2012). A full-length rabies virus nucleoprotein has also been expressed in tomato (Perea Arango et al., 2008), cholera toxin subunit B (CT-B)-rabies glycoprotein fusion protein has been expressed in tobacco (Roy et al., 2010) and tobacco seeds (Tiwari et al., 2009), chimeric peptide containing rabies G protein and $\mathrm{N}$ protein determinants was expressed in tobacco and spinach (Yusibov et al., 2002) and a rabies glycoprotein- ricin toxin $\mathrm{B}$ chain fusion protein has been expressed in tomato hairy roots (Sigh et al., 2015). A similar expression approach that was used by Ashraf et al. (2005) to express a synthetic, codon-optimised $G$ protein gene in tobacco for the first time. Native signal peptide was replaced by $N$. tabacum pathogenesis-related protein PR-S and an ER KDEL signal sequence was added to the $\mathrm{C}$-terminus of the $\mathrm{G}$ protein gene. Selected nuclearly transformed plants expressed G protein at $0.38 \%$ TSP in leaves. Intraperitoneal immunization of mice resulted in protective immunity against intracerebral challenge with live rabies virus. In 2012, Loza-Rubio et al. expressed $\mathrm{G}$ protein in maize seeds and evaluated its immunogenicity in polygastric species for the first time. As a transformation method biolistics was used. The average expression level in obtained transgenic plants was $25 \mu \mathrm{g} / \mathrm{g}$ of fresh tissue, equalizing about $1.4 \%$ TSP, which is the same amount as was obtained in carrot by Anaya et al. (2009). When orally immunized with $2 \mathrm{mg}$ of obtained $G$ protein one single time, sheep (the main victims of rabies infections in Latin America) elicited anti-rabies neutralizing serum $\mathrm{Ab}$ and $\mathrm{a}$ protective immunity against rabies virus infection with a survival rate of $83 \%$ was obtained, the same as the efficiency obtained by inactivated commercial vaccine (Loza-Rubio et al., 2012). Apart from $G$ protein, a full-length rabies virus nucleoprotein ( $\mathrm{N}$ protein) was transiently expressed in Agrobacterium-transformated tomato and $N$. benthamiana plants in 2008 for the first time (Perea Arango et al., 2008). N protein was expressed at levels ranging from $0.1-0.5 \mathrm{mg} / \mathrm{g}$ to $1-4 \% \mathrm{TSP}$ in tomato fruit and up to $4 \mathrm{mg} / \mathrm{g}$ and $45 \%$ TSP in $N$. benthamiana leaves and it was found to have induced $\mathrm{Ab}$ production in both orally and intraperitoneally immunized mice, whereas only $50 \%$ of the latter were protected against a peripheral viral challenge. Yusibov et al. (2002) expressed $\mathrm{G}$ and $\mathrm{N}$ protein in the form of a chimeric peptide together with tobacco virus mosaic proteins in tobacco and spinach. Parenterally immunized mice showed immunity to rabies virus and an anti-rabies immune response was elicited in human volunteers orally immunized by transgenic chimeric peptide from spinach. With the aim of making it more effective, rabies virus proteins have been expressed as fusion proteins with well-known potent mucosal adjuvants. Rabies-CT-B fusion protein has been expressed in tobacco (Tiwari et al., 2009; Roy et al., 2010). In the case of Roy et al. (2010) accumulation level was $0.4 \%$ TSP, fusion protein formed pentameric protein which was biologically active in binding to the GM1 ganglioside receptor. However its in vivo activity and immunogenicity have not been tested. Recently, Singh et al. (2015) expressed rabies virus glycoprotein fused to ricin toxin B chain in tomato hairy roots. Fusion gene construct contained Nterminal ER-trageting Calreticuline signal sequence from tobacco and C-terminal ERretention signal SEKDEL and was under control of CaMV 35S double enhancer promoter. Its expression was between 1.4 and $8 \mu \mathrm{g} / \mathrm{g}$ of tissue, with the highest yield being $1.14 \%$ TSP. The highest yielding tomato line, containing single copy of the transgene stably integrated into nuclear genome, was used in bench-top bioreactor for optimization of scale-up process. By optimizing the cultivation parameters over the span of 3 weeks, the team managed to increase the growth rate in the bioreactor 49.3-fold. Partially purified fusion protein was capable of inducing immune response in intra-mucosally immunized mice (Th2 lymphocite immune response) but due to the low titres of Abs protein quantity should be further optimized in order to obtain better responses both after the primal and booster dose. The use of hairy roots for production of vaccine antigens offers several advantages to their expression in whole plants: the ability to generate plants and store their germplasm long-term, the absence of toxic 
compounds such as alkaloids, obtaining large quantities of protein in short time etc.

\subsection{Rotavirus}

Rotaviruses are the main cause of gastroenteritises in children and animal offspring, causing severe annual economic loses (especially) in cattle; over 500000 annual deaths are estimated in humans, mainly in children living in developing countries in South Asia and sub-Saharan Africa due to insufficient hygienic conditions. Triple-layered rotavirus virions contain a genome of 11 dsRNA encoding 6 structural and 6 non-structural proteins. The capsid has 3 layers, named VP2, VP6 and VP7 (the outermost) with VP4 protein forming spikes on its surface. In the host intestine VP4 gets cleaved to VP5 and VP8* (Pera et al., 2015), especially the latter being highly immunogenic and playing a major role in rotavirus infectivity. The outer capsid layer, VP7, also contains several epitopes, important for viral activity. Therefore, VP7 and VP4 and its derivatives VP8* and VP5 were chosen as main candidate antigens for subunit vaccine development (Bergeron-Sandoval et al., 2011). Rotaviruses are divided into 7 groups (AG). Group A contains 4 sub-groups based on the antigenic properties of VP6. Currently there are around 140 different genotypes of the human rotavirus described (genotype $\mathrm{G}, \mathrm{P}$ or $\mathrm{G} / \mathrm{P}$ ). For human rotavirus there are currently two live vaccines available, monovalent vaccine based on the most common serotype G1P[8] and pentavalentG1-G4 P[8] vaccine. Due to their expensiveness making them unavailable to the majority of the population in the developing world and the recent emergence of several novel serotypes there is however a big demand for developing new and better rotavirus vaccines (Pera et al., 2015), an aim for which also transgenic plants have been utilized a lot during the recent years. Rotavirus capsid proteins have been expressed by various research groups: VP6 has been expressed in tomato (Chung et al., 2000; Chung et al., 2001), alfalfa (Dong et al., 2005), potato (Yu and Langridge, 2003), VP7 has been expressed in potato (Wu et al., 2003; Choi et al., 2005), VP8* in transplastomic tobacco plants (Lentz et al., 2011), bovine VP8* in potato (Matsumura et al., 2002) and $N$. benthamiana in recombinant form (Perez-Filgueira et al., 2004a). In addition, NSP4-CT-B fusion protein has been expressed in potato (Arakawa et al., 2001; Kim and Langridge, 2004), VP6-BSSV fusion protein in Chenopodium amaranticolor (Zhou et al., 2010) and VP2, VP6 and VP7 have been co-expressed in the form of VLPs in tobacco (Yang et al., 2011). These experiments proved that rotavirus coat proteins can be successfully expressed in various plant tissues where they accumulate to relatively high levels, as high as $0.28 \%$ TSP of VP6 in tobacco (Dong et al., 2005) and 1.5\% TSP of rotavirus VLPs in tobacco (Yang et al., 2011). Obtained proteins were also capable of inducing both mucosal and systemic immune response in orally immunized mice as well as provide passive immunity against rotavirus challenge in suckling mice born to immunized mother: $60 \%$ of pups in the case of VP6-BSSV from C. amaranticolor (Zhou et al., 2010), $85 \%$ of pups in case of bovine VP8* from transplantomic tobacco (Lentz et al., 2011) and bovine VP8* from tobacco (PerezFilgueira et al., 2004a). The most recent research includes transient expression of a single antigen and dimeric combinations of human VP7 and truncated VP4 fused with fljB flagelling subunit from Salmonella typhimurium in $N$. benthamiana (Bergeron-Sandoval et al., 2011) and a vaccine candidate against the newly emerged G9P[6] strain, produced by transient expression in $N$. benthamiana (Pera et al., 2015). BergeronSandoval et al. (2011) expressed codon-optimized full-length VP7, truncated VP4 and dimeric combinations of VP7, VP4 and fljB flagellin fused to 5'UTR of tobacco etch virus which works as a transcription enhancer, in leaves of $N$. benthamiana with relatively high yields: $5 \mu \mathrm{g} / \mathrm{g}$ for truncated VP4, $4 \mu \mathrm{g} / \mathrm{g}$ for flagellin, $31.97 \mu \mathrm{g} / \mathrm{g}$ for VP7-flagellin dimer and $12.3 \mu \mathrm{g} / \mathrm{g}$ for VP4flagellin dimer. In the case of VP7 and VP7-VP4 dimer there was mild leaf necrosis whereas all the other proteins were stably expressed. The amount of obtained VP4 was fit to the amount of VP8* previously obtained in $N$. benthamiana plants when TMV-based vector was used for transformation (Perez-Filgueira et al., 2004a). Expression of VP7 however was much lower than that previously reported in transgenic potato tubers (40 $\mu \mathrm{g} / \mathrm{g}$ ) (Li et al., 2006), probably due to differences between the plant systems used, but the system tested in this report provides much faster and efficient production of antigenic proteins than systems using stable transformation. As can be seen, it is possible that fusion of VP proteins with 
flagellin results in much higher protein expression, which could be used in production of rotavirus vaccines. Mice, subcutaneously immunized by VP4 and VP7, generated weak immune responses against rotavirus while mice immunized by dimeric fusion proteins generated strong, anti-flagellin immune response. As flagellin is known to have protected mice against chemical, bacterial, viral and radiation challenge without adverse side effects and induces many different cytoprotectant activities, Bergeron-Sandoval et al. (2011) propose it as a promising candidate for vaccine adjuvant. Pera et al. (2015) in term successfully expressed VP2 and VP6 in the form of VLPs in $N$. benthamiana by transient Agrobacterium-mediated transformation. Because the expression of VP7 and VP4 was not successful, the team tried to produce more appropriately immunogenic particles and created 3 fusion proteins, adding VP8* to the VP6 and co-expressing it with VP2. The team tested the effect of different ODs, intracellular targeting and tomato spotted wilt virus silencing suppressor protein (NSs) on protein expression and yield; they also used the tomato spotted wilt virus suppressor protein in order to optimise the expression. VP6 was successfully expressed in cytoplasm (where the addition of NSs enhanced the accumulation), chloroplasts (where the NSs addition reduced the accumulation), and apoplast and ER (where the NSs addition increased the accumulation on day 3 out of 7, the day on which the expression was at the maximal level). The addition of sequences, targeting the VP6 to intracellular compartments, did not significantly increase its accumulation. VP2 was expressed in cytoplasm, ER, apoplast and chloroplasts only in addition of NSs, at significantly lower average level than VP6. VP7 and VP4 have not been successfully expressed at all. The expression of VP8*/VP6 was only successful when binary plant vector pEAQ-HT was used, but not when plasmids from pTRA family were used. The highly immunogenic epitope of VP8* was fused to either N- or C-terminal end of VP6 and successfully expressed in cytoplasm, whereas $\mathrm{VP} 6 / 8 * \mathrm{C}$ was expressed faster and at higher levels than VP6/8*N. VP2 was coexpressed with all the proteins, expressed in cytoplasm, and was found to be expressed at the highest level when co-expressed with VP6 (Pera et al., 2015). The fusion proteins did not form VLPs but based on previous studies by other authors the team suspects they could still retain their high immunogenicity, which would have to be evaluated in animal experiments.

\subsection{Newcastle disease virus}

Newcastle disease virus (NDV) is the cause of an economically important avian diseases, heavily affecting global poultry industry. The main candidates for developing a vaccine against the disease are fusion protein (F) and hemagglutiningneuraminidase protein $(\mathrm{HN})$ since they are both exposed on the surface of the virus and take part in the infection. HN protein has been expressed in $N$. benthamiana (Gomez et al., 2009; Lai et al., 2013), potato (Berinstein et al., 2005) and tobacco (Hahn et al., 2007), $\mathrm{F}$ protein has been expressed in transgenic rice (Yang et al., 2007), potato (Berinstein et al., 2005) and maize (GuerreroAndale et al., 2006). These experiments proved that $\mathrm{HN}$ and $\mathrm{F}$ proteins can be successfully expressed in transgenic plants and that obtained proteins are immunogenic when delivered to either mice or chickens. Both maize-produced NDV F protein (Guerrero-Andrade et al., 2006) and tobacco-produced HN protein (Hahn et al., 2007) have been found to be immunogenic in orally immunized chickens; oral immunization with $\mathrm{F}$ protein gave $100 \%$ protection of chickens against nasal challenge with NDV, while in the case of HN protein protection against nasal NDV challenge failed but the authors reported a big increase in anti-HN serum IgG levels 28 days after vaccination, increased by 2 -fold in $40 \%$ of examined chickens and 4-fold in $20 \%$ of examined chickens (Hahn et al., 2007). HN and F proteins, co-expressed in potato, have been shown to elicit anti-NDV antibodies in intraperitoneally immunized mice and serum IgG at levels comparable to those elicited in mice fed with nontransformed plants soaked in NDV (Berinstein et al., 2005), while the intestinal fluids of those mice also showed considerable IgA and IgG levels. F protein, stably expressed under ubiquitin promoter or rice glutelin promoter in rice, elicited anti-NDV serum IgG in intraperitoneally immunized mice (Yang et al., 2007). From the point of view of expression level for each of the expressed protein it was noted that $\mathrm{F}$ protein was expressed higher in maize kernels than in rice $(0.9-3 \%$ TSP and $0.0025-0.0055 \%$ TSP, respectively) (GuerreroAndrade et al., 2006; Yang et al., 2007), while the expression of HN protein was higher when coexpressed with $\mathrm{F}$ protein in potato than when 
expressed on its own in tobacco $(0.3-0.6 \mu \mathrm{g} / \mathrm{g}$ total leaf protein and $0.069 \%$ TSP, respectively) (Berinstein et al., 2005; Hahn et al., 2007). When transiently expressed in $N$. benthamiana as a $\mathrm{pSPhnHN/KDEL}$, under the control of rubisco small subunit promoter, fused to its own KDEL ER retention signal, recombinant $\mathrm{pSPhnHN/KDEL}$ protein accumulated to the highest levels from all of the 5 tested constructs (Gomez et al., 2009). When potato was transformed with $\mathrm{pSPhnHN} / \mathrm{KDEL}$ as described by Berinstein et al. (2005), the protein expression was as high as 3 $\mu \mathrm{g} / \mathrm{g}$ of total leaf protein, which is 10 -fold higher than levels obtained by expression of $\mathrm{HN}$ under the control of $\mathrm{CaMV} 35 \mathrm{~S}$ promoter in potato (Berinstein et al., 2005). In 2006, US Department of Agriculture Center for Veterinary Biologics gave regulatory approval and a license to Dow Agro Sciences LLC for an injectable vaccine against NDV based on $\mathrm{HN}$ protein produced in tobacco suspension cell line. In a proof-of-concept study, two subsequent immunizations gave $90 \%$ protection of birds against a lethal virus challenge (Gomez-Lim, 2014). This vaccine is the first fullylicensed plant-cell-produced vaccine for animals in the United States and the first plant-made product to be licensed by USDA's Animal and Plant Health Inspection Service (USDA ..., 2006). The company has, however, shown no interest in commercialization of the vaccine up to date. With the aim of improving the $\mathrm{HN}$ expression in plant host system, Lai et al. (2013) recently expressed functional ectodomain of $\mathrm{HN}$ protein $(\mathrm{eHN})$ from NDV strain AF2240 in N. tabacum BY-2 cells, which had been proven suitable for production of various recombinant proteins. The eHN translation was enhanced by 5'-UTR region of $N$. tabacum alcohol dehydrogenase gene driven by CaMV 35S promoter. An eHN cDNA was successfully integrated into plant cell genome and actively transcribed. For all 8 transformants showing the highest levels of eHN mRNA transcripts, immunoblot detected a protein band the size of 66 $\mathrm{kDa}$, corresponding to the predicted $\mathrm{eHN}$ molecular weight. The eHN protein expression was stable and accounted up to $0.2-0.4 \%$ TSP, significantly more than in previous studies (Hahn et al., 2009; Gomez et al., 2009) using strong constitutive promoter and translation enhancer sequence. Localization of eHN-GFP in BY-2 protoplasts showed predominant accumulation of the protein in cytosol. Mice, intraperitoneally immunized with $5 \mu \mathrm{g}$ of purified plant-produced eHN in incomplete Freund adjuvant 4 times, elicited anti-NDV antibodies, immune response enhancing with each additional boost and reaching the peak by day 67 (Lai et al., 2013). Similar responses were obtained in mice immunized with full-length potato- and tobacco-produced $\mathrm{HN}$ (Berinstein et al., 2005; Hahn et al, 2007, respectively). These results proved that truncated $\mathrm{HN}$ protein, lacking the transmembrane domain, still maintains its biological and functional activity in murine model and is capable of inducing an immune response closely resembling that of the native protein, so it can serve as a promising candidate antigen for development of a NDV subunit plant-made vaccine.

\subsection{Norwalk virus capsid protein}

Norwalk virus is the cause of epidemic acute gastroenteritis in humans both in developed and developing countries. It spreads via water, food and human contact. $42 \%$ of acute epidemic gastroenteritis in the United States is estimated to be caused by Norwalk virus (Tang and Page, 2013). Currently there is no Norwalk virus vaccine available. The main candidate antigen for its development is, however, Norwalk virus capsid protein (NVCP), which has been expressed in the form of virus-like particles (VLPs) in potato and tobacco (Mason et al., 1996), potato tubers (Tacket et al., 2000), tomato fruit (Huang et al., 2005), Nicotiana benthamiana (Santi et al., 2008; Huang et al., 2009; Souza et al., 2013) and lettuce (Lai et al., 2012). Immunogenicity of produced VLPs has been evaluated in mice, fed by gavage (Mason et al., 1996), human volunteers (Tacket et al., 2000) and orally immunized mice (Huang et al., 2005; Santi et al., 2008). Evaluated VLPs have been found capable of inducing sufficient antigenspecific systemic and mucosal immune response, even in the case when freeze-dried transgenic NVCP tomato fruit was used (Huang et al., 2005). Protein accumulation in transgenic tomato was much higher than in potato tubers, $26.7 \mu \mathrm{g} / \mathrm{g}$ in tomato fruit and $1.4-3.6 \mu \mathrm{g} / \mathrm{g}$ in potato tubers (Huang et al., 2005; Tacket et al., 2000, respectively). The best expression of the NVCP was obtained when the first two Met residues of the N-terminus had been eliminated from the native NVCP (Huang et al., 2005). Santi et al. (2008) developed an efficient tobacco mosaic 
virus- derived transient expression system and successfully expressed NVCP in leaves of $N$. benthamiana at levels $0.8 \mathrm{mg} / \mathrm{g} 12$ days postinfection as a more rapid alternative to expressing NVCP in plants and found it to be immunogenic in orally immunized mice. The procedure of expressing NVCP VLPs has been further improved by Huang et al. (2009) who optimized geminivirusderived DNA replicon vectors for expression of hepatitis B core antigen and NVCP in $N$. benthamiana leaves. Using bean yellow dwarf virus-derived vector and Rep/RepA-supplying vector for agroinfiltration of leaves and coexpressing the tomato bush stunt virus $\mathrm{P} 19$ protein as a mRNA stabilizator the team was able to greatly enhance the transgene expression and shorten the time needed for the final product, thereby producing as much as $0.34 \mathrm{mg} / \mathrm{g} \mathrm{NVCP}$ VLPs in 5 days' time. The same system was tested in lettuce by Lai et al. (2012). NDCP was found correctly expressed in lettuce leaves, with the highest accumulation at 4 days post-infection and an average expression level of $0.2 \mathrm{mg} / \mathrm{g}$. This is comparable to the results of Huang et al. (2009) and is the highest expression level of any nonchloroplast-derived vaccine component ever reported in lettuce plants (Lai et al., 2012). Recently, Souza et al. (2013) tried to optimize expression of norovirus-like particles, such as NVCP-VLPs, in plants, utilizing a binary vector and co-expression of PTGS suppressor to increase the target protein yield. In the series of experiments in Agrobacterium-transformed $N$. benthamiana leaves, the team first examined the effect of 4 post-transcriptional gene silencin (PTGS) suppressors on protein expression with GFP as a reporter in $N$. benthamiana co-infiltrated with PTGS and GFP, recording the observed amount of GFP. The most effective PTGS, 126 $\mathrm{kDa}$ Pepper mild virus protein, was then used for co-expression with major and minor capsid genes of NVCP ( $v p 1$ and vp2, respectively) with a 3'UTR. Obtained VLPs were purified by sucrose gradient centrifugation. While the previous studies all used so-called magnICON viral vectors and transient expression systems, this is the first trial of expressing inserts, longer than just vp1 in plant expression systems. Even though the team used $N$. benthamiana -optimized codons, the expression level remained the same as that of $\mathrm{vp} 1$ isolated from the virus itself. Tang and Page (2013) adapted the glucocorticoid-inducible expression system developed by Aoyama and Chua (1997) and Ouwerkerk et al. (2001), to express NVCP in Agrobacterium-transformated cell suspension cultures of tobacco, rice, slash pine and cotton, using dexamethasone (DEX) as an expression inducer. Transformation vector contained hygromycin phosphotranspherase, chimeric transcription factor GVG and NVCP gene. For each plant species, the effect of different dexamethasone concentrations $(1.25,2.5,5,10,20$ and $40 \mathrm{mg} / \mathrm{l}$ ) on transgene expression have been tested. For all concentrations there was clear transgene expression 2 days after the addition of the inducer to the medium, and no expression of the transgene was found in plants with no inducer added. Maximum NVCP expression was obtained at $10 \mathrm{mg} / \mathrm{g} \mathrm{DEX}$; greater concentrations were deleterious to transgene expression.

\subsection{HIV}

Human immunodeficiency virus type 1 (HIV-1) is the cause of AIDS (acquired immunodeficiency syndrome), a deadly infectious global disease, affecting more than 34 million people worldwide (Lotter-Stark et al., 2012). The great genetic variety among HIV-1 subtypes, high mutation rate and biological properties of HIV-1 regulatory proteins by avoiding immune response (Cueno et al., 2010) significantly worsen the process of developing an efficient vaccine. Various HIV proteins have been expressed in plant systems so far: HIV-1 p24 in tobacco (Zhang et al., 2002; Perez-Filgueira et al., 2004b) and A. thaliana (Lindh et al., 2014), HIV 1 P55 Gag polyprotein in tobacco chloroplasts (Scotti et al., 2009) and tobacco plants both in full length and truncated form (Meyer et al., 2008), HIV-1 Tat in potato (Kim and Langridge, 2004a) and tomato (Cueno et al., 2010), HIV-1 Nef in tobacco (Marusic et al., 2007) and $N$. benthamiana (Lombardi et al., 2009; Circelli et al., 2010), HIV-1 CA capsid protein VLPs in Lycium barbarum (Du et al., 2004), HIV$1 / \mathrm{HBV}$ fusion protein has been expressed in tobacco (Greco et al., 2008; Guetard et al., 2008) and A. thaliana (Greco et al., 2008). Tat regulatory element of the simian-HIV-1 virus (SHIV 89.6 Tat) has also been expressed in potato ( $\mathrm{Kim}$ and Langridge, 2004b), fused to cholera toxin subunit B. As an important early marker of HIV-1 infection p24 protein, a major component of the gag polyprotein, is a promising candidate for developing an oral vaccine used to offer immediate

Acta agriculturae Slovenica, 107 - 1, marec 2016 
protection of the gut-associated lymphoid tissue (GALT) against HIV-1 challenge. The first researches in expressing p24 in plants were done by Zhang et al. (2002), who stably expressed p24 gene cassette it in Agrobacterium-transformated tobacco with the average yield $3.5 \mathrm{mg} / \mathrm{g}$ leaf soluble protein and was proven antigenic by Western blot. Perez-Fligueira et al. (2004b) modified tobacco mosaic virus TMV-30B to express HIV-1 p24 in tobacco. The addition of 7 His residues to the $\mathrm{C}$-terminal end of the transgene was used to transiently express HIV-1 p24 in tobacco leaves with yields as high as $2.5 \mathrm{mg}$ of purified p24/25 g of leaf tissue, which would suffice for 20000 routine diagnostic tests for HIV1 as carried out in accordance with the WHO standards. Rabbits, immunized with purified p24 diluted in buffer in the presence of Freund adjuvant, developed a specific anti-p24 humoral response following the second immunization and p24 was also proven functional when used for Western blot assay to confirm HIV-1 test results in a set of Zambian patients. So despite the denaturating conditions, IMAC columns, used to purify p24 expressed by TMV-p24-HISc modified vector, the protein retained its function and efficiency. In 2011, Gonzales-Rabade et al. reported a successful expression of HIV-1 p24 and HIV-1 p24-Nef fusion protein in the chloroplasts of transplastomic tobacco. Expression levels obtained in leaves were $4-40 \%$ TSP. Oral immunization of mice by gavage, with CT-B as an adjuvant (ratio p24:CT-B 1:1, i.e. $10 \mu \mathrm{g}$ of each), elicited strong p24-specific serum IgG responses, with IgG sub-clases found in sera of immunized mice after subcutaneous immunization indictating activation of humoral immune response as well. Recently, Lindh et al. (2014) carried out a series of experiments, using previously obtained transgenic carrots, expressing $90 \mathrm{ng} / \mathrm{g} \mathrm{FW}$, and high- and lowyielding $A$. thaliana (expressing $366 \mathrm{ng} / \mathrm{g}$ and 34 or $17 \mathrm{ng} / \mathrm{g} \mathrm{FW}$, respectively) were used for oral immunization of mice. Both plants were used in either fresh or freeze-dried form. 6/7 experiments contained fresh plant tissue and 1 freeze-dried, mice in $4 / 7$ experiments were allowed to feed freely and 3 controlled by tube feeding. The effect of the plant tissue for all experiments was evaluated by ELISA, two weeks after the p24 intramuscular boost. In the case of carrot, high amounts of p24-specific IgG were found in sera of immunized mice 2 weeks after the boost.
Immunization with freeze-dried $A$. thaliana by gastric tube did not result in detectable p24specific Abs while immunization with fresh tissue gave results similar to those in the case of transgenic carrot. Interestingly, mice immunized with low-level p24 extract had higher response to the antigen boost while mice immunized with high-level p24 extract had much weaker immune response. When CT-B was added to the antigen, there was no serum immune response whatsoever. In the case of free feeding, anti-p24 IgG were observed in the serum of mice fed with low-level p24 A. thaliana after the p24 boost, while no antip24 IgG were detected in the serum of mice fed high-level p24 A. thaliana. This was the first dosedependent HIV-1 p24 antigen delivery study using transgenic Arabidopsis (Lindh et al., 2014). Immunizations with fresh transgenic carrots (nonmandatory eating, free feeding, $720 \mathrm{ng}$ p24/dose) induced anti-p24 IgG response in the serum, following the p24 boost, however the observed $\operatorname{IgG}$ levels were low. Fresh $A$. thaliana free feeding induced weak IgG response no matter which dose was delivered $(28,200,620 \mathrm{ng}$ or $2.2 \mu \mathrm{g}$ p24/dose). Low-level p24 extract fed by tube (20 ng/dose) was more efficient than high-level extract (460 ng/dose), results supporting the threshold value of $20 \mathrm{ng}$ of antigen as a minimum to induce detectable immune response, as described by Beyer et al. in 2007.

\subsection{Avian influenza virus H5N1}

Highly pathogenic avian influenza is a deadly disease that had initially been affecting only poultry, thus causing great economic losses, but has also been representing a serious risk for human health since the first outbreak of highly pathogenic influenza (H5N1) in humans in Hong Kong in 1997 (Guo et al., 2012) in Asian countries as well as in Europe and Africa. Development of safe, cost-effective and efficacious vaccines is thus needed to reduce the economic impact of the disease on agriculture and prevent possible future pandemic outbreaks. The cause of the disease is highly pathogenic influenza A virus subtype H5N1. The main targets for subunit vaccine development have been its principal surface antigen hemagglutinin (HA), which plays a major role in functional activity of the virus and is also a main target for neutralizing antibodies of the host, and the M2e viral peptide, the extracellular domain 
of the viral protein M2, which is highly conserved between various influenza strains and therefore a promising candidate for a universal influenza vaccine. H5N1 HA has been expressed in $N$. benthamiana in full-length (Kalthoff et al., 2010) and in the form of VLPs (Landry et al., 2010), in Lotus corniculatus (Guo et al., 2012) and most recently, duckweed (Bertran et al., 2015). In addition, recombinant $\mathrm{HA}$ from $\mathrm{A} /$ Bar-headed Goose/Qinghai/1A/05 (clade 2.2) and A/Anhui/1/2005 (clade 2.3) have been expressed in $N$. benthamiana (Shoji et al., 2009). Kalthoff et al. (2010) were the first to evaluate the immunogenicity of plant-produced full-length HA in chicken. Using different magnICON vectors, HA was targeted either to cytosol, apoplast or chloroplasts and the apoplast-targeted HA was expressed at the highest level $(0.3 \mathrm{~g} / \mathrm{kg}$ of fresh leaf biomass), especially when tobacco calreticulin signal peptide was used. Chickens, intramuscullary immunized with vaccine containing HA with copolymer, catatonic lipid-DNA complex or Freund adjuvant, elicited strong neutralizing $\mathrm{Ab}$ responses against $\mathrm{H} 5 \mathrm{~N} 1$ and were protected against the lethal virus challenge. Landry et al. (2010) reported the ability of alum-adjuvanted H5N1 HA VLPs to induce cross-reactive anti-H5N1 antibodies in ferrets as well as good tolerance and immunogenicity of the experimental alumadjuvanted vaccine in adult human volunteers in Phase I clinical trial. Immunization with HA did not trigger an immune response to plant-specific carbohydrate determinants neither were the known allergies to plant derivatives or presence of detectable anti-plant-specific glycans IgG levels lead to immune response against $\mathrm{N}$-glycans present on the HA used in vaccine (Kalthoff et al., 2010). Recently, this founding was supported by the results of the research carried out by Ward et al. (2014), who evaluated the immune and possible allergic response to $N$. benthamiana-produced VLPs carrying HA from $\mathrm{H} 5$ or $\mathrm{H} 1$ influenza viruses, in 280/349 humans. Subjects were intramuscularly immunized with 1 (H1) or 2 (H5) doses of 5-45 $\mu \mathrm{g} \mathrm{HA}$ /dose and monitored for 6 months. $34 \%$ of them developed transient IgG and in some cases IgE against plant glyco-epitops but no hypersensitivity or allergy was observed. Guo et al. (2012) were the first to successfully express biologically functional H5N1 HA in $L$. corniculatus, the gene expression being driven by $\mathrm{CaMV} 35 \mathrm{~S}$ promoter, using Agrobacterium- mediated transformation. Transformation frequency in successfully transformed cotyledon fragments was $58.8 \%$ as determined by PCR or Southern blot analysis, while transformation of hypocotyl gave no results. Using pBI-MARS-HA plasmid resulted in HA expression with the maximum of $0.00786 \%$ TSP, much higher than in the case of pBI-HA plasmid $(0.00408 \%$ TSP), which, considering the use of $L$. corniculatusoptimized codons, MARS and CaMV 35S promoter, is still very low. Recently, synthetic HA gene from $\mathrm{H} 5 \mathrm{~N} 1$ virus $\mathrm{A} /$ chicken/Indonesia/7/2003 (Indo/03) was expressed in duckweed. Its efficacy was first tested in birds immunized with $0.2 \mu \mathrm{g}$ or $2.3 \mu \mathrm{g}$ HA and challenged with $10^{6}$ mean chicken embryo infectious doses (EID50) of homologous virus strain (Bertran et al., 2015) and in birds immunized with $0.9 \mu \mathrm{g}$ or $2.2 \mu \mathrm{g}$ HA challenged with $10^{6}$ EID50 of heterologous H5N1 virus strains $\mathrm{A} /$ chicken/Vietnam/NCVD-421/2010 (VN/10) or A/chicken/West Java/PWT-WIJ/2006 (PWT/06) (Bertran et al., 2015). Almost all birds immunized with 0.2 or $2.3 \mu \mathrm{g}$ of $\mathrm{HA}$ elicited anti-Indo/03 antibodies and were protected against homologous virus challenge, $100 \%$ of birds immunized with either dosage of HA showed protection against $\mathrm{VN} / 10$ challenge while birds challenged with PWT/06 showed $50 \%$ mortality when immunized with $0.9 \mu \mathrm{g}$ HA and $30 \%$ mortality when immunized with $2.2 \mu \mathrm{g}$ HA. Only birds challenged with VN/10 developed humoral immune response against the challenge antigen. Shoji et al. (2009) expressed 2 strains of H5N1 in $N$. benthamiana. Sequences for each gene were optimized for plant expression using tobacco PR-1 signal peptide at the $\mathrm{N}$-terminus and ER retention signal KDEL and poly-histidine tag at C-terminus and Agrobacterium-mediated transformation was performed. Subcutaneous immunization with purified antigen from both strains elicited hemagglutinin inhibition (HI) and virus neutralizing (VN) antibodies in mice, with $\mathrm{HI}$ titers $>1: 40$, which is the minimal titer consistent with protective immunity in humans. M2e has been expressed in tobacco (Tarasenko et al., 2013) and recently, in duckweed (Firsov et al., 2015) and also in a form of a hybrid protein M2eHBC, fused to hepatitis B core antigen (Ravin et al., 2012). Tarasenko et al. (2013) expressed synthetic, codonoptimized 22-, 30- or 43-amino acids long terminal fragments of the M2 protein, encoding 3 different variants of M2e peptide (M122, M130 and M143, 
respectively, with M122 and M130 encoding truncated M2 protein variants), fused with Nterminus of $\beta$-glucuronidase, in Agrobacteriumtransformed $N$. tabacum. Transformation by vectors containing M122 or M130 resulted in successful expression of both variants of M2e peptide, in the form of M122- $\beta$-glucuronidase and M130- $\beta$-glucuronidase fusion proteins. In plants transformed with vector containing M143 gene for non-truncated M2e, the protein was observed only in plants grown in vitro and disappeared when the plants were transported into greenhouse. M2eHBC hybrid protein has been transiently expressed in $N$. benthamiana using a recombinant potato $\mathrm{X}$ virusbased viral vector. M2 $\mathrm{eHBc}$ accumulated in leaf tissue at amount $1-2 \%$ TSP in the form of VLPs. Immunogenicity of the VLPs was evaluated in intraperitoneally immunized mice. Three-fold immunization induced high titers of serum $\operatorname{IgG}$ targeting both the synthetic polypeptide, used in immunization (M2eHBc polypeptide G19) and its corresponding peptide sequence from heterologous influenza virus strain. $90 \%$ of the immunized mice was protected against the lethal influenza virus challenge. Recently, Firsov et al. (2015) successfully expressed M2e peptide in the form of M2e- $\beta$-glucuronidase fusion protein in Agrobacterium-transformed duckweed. The team expressed 30 amino acids long $\mathrm{N}$-terminal fragment of M2 protein, containing 24 amino acid long fragment encoding M2e, optimized for expression in duckweed and fused upstream of the $\beta$-gucuronidase gene, under the control of $\mathrm{CaMV}$ $35 \mathrm{~S}$ promoter. Stably transformed plants were obtained (nuclear transformation) with the highest yield of M2e- $\beta$-glucuronidase fusion protein being 1.89 and $1.96 \%$ TSP $(0.82$ and $0.97 \mathrm{mg} / \mathrm{g}$ fresh weight, respectively, Firsov et al., 2015), accounting for app. $40 \mu \mathrm{g} / \mathrm{g}$ of fresh weight of M2e alone. The protein accumulated in cytoplasm. The expression levels were similar to those previously obtained in experiments using virus-based transient expression systems, which is especially attractive as it could make duckweed a promising candidate for large scale production of influenza vaccine with regards to being able to produce equal amounts of protein than transient expression system at lower cost.

\section{BACTERIAL VACCINES}

\subsection{Escherichia coli heat-labile enterotoxin subunit B}

Enterotoxigenic Escherichia coli (ETEC) is the leading cause of diarrhea in developing world, causing severe mortality and morbidity rates especially in children up to 5 years of age in the developing coutries. Enterotoxigenic strains of $E$. coli produce either the heat-stable toxin (ST), the heat-labile toxin (LT) or both. The structure and function of LT are highly similar to those of the cholera toxin. The B subunit of LT (LT-B) is nontoxic and works as a potent mucosal immunogen therefore it has been used as a target in developing candidate vaccines against ETEC-caused diarrhea as well as against cholera toxin, because the antitoxin response caused by immunization with LT-B also extends to CT-B. Since the first LT-B subunit was expressed in potato and tobacco (Haq et al., 1995) many plant expression models have been developed and tested: tobacco leaf (Haq et al., 1995; Wang et al., 2001; Kang et al., 2006a; Chia et al., 2011), potato tubers (Mason et al., 1998; Tacket et al., 1998; Lauterslager et al., 2001), maize seeds (Streatfield et al., 2001; Chikwamba et al., 2002), tobacco chloroplasts (Kang et al., 2004a), tobacco mosaic virus infected $N$. benthamiana plants (Wagner et al., 2004), transgenic corn (Tacket et al., 2004), Siberian ginseng somatic embryos (Kang et al., 2006b), carrot (Rosales-Mendoza et al., 2007; 2008), soybean seed (Moravec et al., 2007), lettuce leaf (Kim et al., 2007; Martinez-Gonzales et al., 2011), Peperomia pellucida tissue culture (Loc et al., 2010), watercress (Loc et al., 2011a) and transgenic tomato fruit (Loc et al., 2011b; Loc et al., 2014). In general, these models proved that synthetic non-toxic LT-B can be produced in plants without losing its native antigenicity or immunogenicity. Obtained yields ranged between 0.3 and $3 \%$ TSP, with the highest yield of $3.3 \%$ TSP in tobacco (Kang et al., 2006a) and $3.7 \%$ TSP in maize seed (Chikwamba et al., 2002) and the lowest reported yields of $0.001 \%$ TSP in the first transformed tobacco leaf and potato (Haq et al., 1995), $0.05 \%$ TSP in lettuce leaf (MartinezGonzales et al., 2011) and $0.095 \%$ TSP in tobacco leaf (Wang et al., 2001). As in the case of other 
plant-made vaccines it has been proven that the addition of protein targeting sequences such as ER SEKDEL and the use of plant-preferred codons contributes to higher expression and accumulation of LT-B in plant tissue and most of the research is focused on searching for plant species that would express a sufficient amount of LT-B and could deliver it to the patient in raw unprocessed form. LT-B expressed in lettuce leaves (MartinezGonzales et al., 2011) elicited both serum and intestinal $\mathrm{Ab}$ responses in orally immunized mice, even in the case of freeze-dried lettuce tissue, with elicited antibodies showing neutralizing activity against cholera toxin challenge. Mice immunized with $8 \mu \mathrm{g}$ of LT-B were fully protected against CT in the same way as mice immunized with the pure yeast-produced LT-B. Lettuce-derived LT-B assembled into pentameric forms, similar to the watercress-derived LT-B (Loc et al., 2011b). LT-B expression in lettuce was deemed stable as expression levels in $\mathrm{T} 1$ generation were similar to those in T2. Plant-derived LT-B has been found to be immunogenic and protective in orally immunized mice models for a majority of abovementioned plant expression models. In addition to that, LT-B expressed in potato tubers (Tacket et al., 1998) and transgenic corn (Tacket et al., 2004) was also immunogenic, protective and well tolerated in orally immunized humans. LT-B expressed in corn seeds (Karaman et al., 2006) elicited both mucosal and systemic immune responses in both young and aged mice and boosting by oral administration or injection of LB$\mathrm{T}$ dramatically increased IgA and IgG levels in aged mice, which could be an indicator of immunological memory assembly. When expressed in transgenic tobacco chloroplasts, the LT-B accumulation was app. $2.5 \%$ TSP, app. 250fold higher than in plants generated by nuclear transformation (Kang et al., 2004). In addition to being expressed independently, LT-B is often expressed as an adjuvant for co-administered antigens, one of such experiments was carried out by Chia et al. (2011), expressing a fusion protein of PRRSV GP5 and LT-B in transgenic tobacco and its immunogenicity was evaluated in orally immunized pigs. It was found that the GP5-LT-Btreated pigs developed PRRSV-specific Ab- and cell-mediated immune response, but their ratios were not significantly higher than those observed in GP5-immunized pigs. Loc et al. (2014) recently expressed LT-B in the fruits of Agrobacterium- transformated tomato. LT-B was expressed in the form of pentamers in the fruits in $2 / 5$ transgenic tomato plants but thus obtained LT-B pentamers specifically bound to GM1 ganglioside, confirming their biological activity, which gives hope for tomato-produced LT-B as a suitable candidate for new-age subunit vaccine, however in vivo immunogenicity studies need to be performed.

\subsection{Cholera toxin subunit B}

Cholera is a highly epidemic diarrheal disease caused by the cholera toxin of enterotoxigenic Vibrio cholerae strain, affecting especially children in developing countries. The pentameric B subunit of the cholera toxin, CT-B, is structurally and functionally very similar to LT-B and has thus been the main target for developing plant-produced candidate vaccines against cholera as well as traveler's diarrhea. CT-B has been expressed in potato (Arakawa et al., 1997; He et al., 2007; Mikschofsky et al., 2009), tobacco (Daniell et al., 2001; Kang et al, 2004b, Kang et al., 2006c; Mishra et al, 2006; Mikschofsky et al., 2009; Tiwari et al., 2009; Rattanapisit et al., 2013), carrot (Kim et al., 2009), tomato leaves and fruit (Meena et al., 2002; Jiang et al., 2007; Loc et al., 2011b), lettuce (Huy et al., 2011), rice (Soh et al., 2015) and maize seeds (Karaman et al., 2012). As it is a potential mucosal and parenteral adjuvant and an effective carrier for chemically or genetically linked antigens, CT-B has often been expressed in the form of fusion proteins with antigens which do not induce sufficient immune response when orally applied on their own, much like LT-B. Examples of such use are CT-B- neutralizing epitope of the porcine epidemic diarrhea virus fusion protein (sCTB-sCOE) in lettuce (Huy et al., 2011), CT-Brabies glycoprotein fusion protein expressed in tobacco seeds (Tiwari et al., 2009), CT-B- Vibrio cholera accessory colonization factor subunit A (ACFA) fusion in tomato (Sharma et al., 2008), fusion of simian-human immunodeficiency virus regulatory sequence and CT-B (Kim and Langridge, 2004b), simian immunodeficiency virus Gag p27 capside protein-CT-B fusion (Kim et al., 2004a) and CT-B- anthrax lethal factor fusion in potato leaf (Kim et al., 2004b), CT-B- human insulin B chain in tobacco (Li et al., 2006) and CTB- rotavirus enterotoxin NSP4 fusion protein in potato tubers ( $\mathrm{Yu}$ and Langridge, 2001). Expression levels of CT-B in most plant systems were $0.01-1 \%$ TSP, with the lowest yield of 
$0.04 \%$ TSP in tomato leaf and fruit (Jani et al., 2002) and the highest yield of $4 \%$ TSP in tobacco leaf (Daniell et al., 2001). In the case of CT-Bfusion proteins, the expression levels were lower, ranging $0.002-0.2 \%$ TSP, the lowest obtained expression being $0.0003 \% \mathrm{FW}$ in potato tubers (Yu and Langridge, 2001) and the highest expression of $0.4 \%$ TSP in tobacco (Roy et al., 2010). In general, expression of synthetic CT-B with plant-optimized codons, additional protein targeting sequences and driven by powerful plant promotors, was much higher than expression of other CT-B forms. When CT-B was expressed under the control of $35 \mathrm{~S}$ CaMV promoter, using plant-optimized codons and additional ER SEKDEL retention signal its expression increased 10 -fold, from previously obtained $0.081 \%$ TSP (Jiang et al., 2007) to 0.9\% TSP (Loc et al., $2011 \mathrm{~b})$. Some of the plant-produced CT-B have been evaluated for their immunogenicity and protection in mice models, applied either orally or by gavage and it has been found that CT-B was immunogenic in all cases and has also induced protection in the form of both mucosal and systemic immune response (Jian et al., 2007; Huy et al., 2011; Karaman et al., 2012) in most cases, while in the case of CT-B-NSP4 rotavirus fusion protein it induced passive immunity ( $\mathrm{Yu}$ and Langridge, 2001). However it has to be noted that in most cases when CT-B was expressed in plant host systems, either on its own or as a part of fusion proteins, its immunogenicity was not evaluated. In 2012, Karaman et al. expressed a synthetic CT-B gene, driven by $\gamma$-zein promoter in transgenic maize seeds and evaluated its immunogenicity in orally immunized mice. The highest expression levels in T1 seeds was 0.0014 of total aqueous soluble protein (TASP) while it increased to $0.0197 \%$ TASP in T2 seeds, suggesting that the CT-B expression could be enhanced through selective breeding to advanced generations. Obtained CT-B was found to be immunogenic in mice and induced both mucosal and systemic immune response as shown by fecal IgA and serum IgG against both CT-B and LT-B, however the effect of serum anti-CT-B IgG on LT$\mathrm{B}$ is not as big as its effect on CT-B and both enterotoxins show significant crossimmunoreactivity (Soh et al., 2015). It was suggested that the combined application of CT-B and LT-B could be an efficient way of protection against both cholera and diarrhea (due to similar enterotoxin structure and mechanism of action). Soh et al. (2015) co-expressed recombinant LT-B and CT-B in rice grain for the first time. Both genes were driven by constitutive globulin promoter, an Agrobacterium-mediated transformation was performed and the obtained transgenic plants were grown to maturity to obtain 5 generations of transgenic seeds. Expression levels in the $5^{\text {th }}$ generation of homozygous seeds as evaluated by ganglioside-dependent ELISA were $3.4 \mathrm{ng} / \mathrm{ug}$ of TSP for LT-B and $21.3 \mathrm{ng} / \mathrm{ug}$ of TSP for CT-B. Obtained CT-B and LT-B were present in their native pentameric form and capable of inducing both mucosal and systemic immune responses in orally and intraperitoneally immunized mice. When applied intraperitoneally, a dose of $100 \mu \mathrm{g}$ rice-produced LT-B and CT-B induced LT-B and CT-B-specific IgG production with similar expression levels. When applied orally, rice-produced LT-B induced both mucosal and systemic IgA production. These findings suggest that mucosal and systemic immune response against both CT-B and LT-B is enhanced by co-administration of both antigens and strengthens the immune response in either orally or intraperitoneally immunized mice. This could be of help with developing edible vaccines against cholera and traveller's diarrhea in economically important crop species like rice and maize. CT-B and LT-B synergism could be further enhanced by breeding to advanced generations and the immunogenic and adjuvant abilities of the coexpressed fusion toxins in rice should be further evaluated in animal studies (Soh et al., 2015). Rattanapisit et al. (2013) have developed a method of rapid transient expression of CT-B in $N$. benthamiana, using geminiviral replicon system, Agrobacterium-mediated transformation and a plant-optimized CT-B sequence. The highest obtained CT-B expression level was app. $4 \mu \mathrm{g} / \mathrm{g}$ fresh weight $\sim 0.14 \%$ TSP as obtained on day 4 , which was much higher than CT-B level transiently expressed in tobacco (Wang et al., 2001). Expressed CT-B showed biological activity for binding on the GM1-ganglioside in GM1ELISA and could be thus a promising candidate for adjuvant for mucosal vaccines. The study suggests that geminiviral system could be efficiently used for high level expression of CT-B and further optimized, especially with regards to possible side effect of gene silencing. 


\section{OTHER RECENT VACCINES}

\subsection{Artherosclerosis}

As an effort to develop immunotherapeutic treatments against artherosclerosis, different vaccination strategies have been proposed during the last 20 years. Most of these strategies were focused on targeting apolipoprotein B100 (ApoB100) and cholesterilester transferase protein (CETP), trying to elicit immune response capable of modulating either arterosclerosis-associated inflammatory reactions or other up-regulated physiological mechanisms leading to this medical condition. To date, several clinical trials on plantbased vaccines against artherosclerosis have been reported: CTEP-tetanus toxin fusion (rabbits), CETi-1 with tetanus toxin as an adjuvant (humans), RHSP65-CETP (rabbits), p45 with $\mathrm{AlOH}$ as an adjuvant (mice), CT-B-p210 (mice) (Salazar Gonzales and Rosales-Mendoza, 2013), with some kind of artheroprotection reported in all cases, mostly shown as IgG or IgA. With the aim of initiating the development of a plant-based artherosclerosis vaccine, Salazar-Gonzales et al. (2014) constructed a synthetic gene encoding a fusion protein consisting of CT-B, CETP and ApoB 100 and expressed it in tobacco. Epitopes of both ApoB100 and CETP were fused at the Cterminal end of CT-B, creating CTB:p210:CETP under the control of CaMV $35 \mathrm{~S}$ promoter. The total of 6 transgenic tobacco plants was obtained, all of them containing transgene. Chimeric CTB:p210:CETP was expressed in tobacco in correctly assembled pentameric form, at the highest yield of $10 \mu \mathrm{g} / \mathrm{g}$ of fresh leaf tissue as obtained from the lines with single copy transgene insert. GM1-ELISA and Western blot analysis proved that the protein retained the target antigenic determinants. Subcutaneous administration of the chimeric protein elicited humoral responses against CETP and ApoB100 epitopes as well as human serum proteins in mice. These findings evidenced for the first time that atherosclerosis-related epitopes can be expressed in plants retaining immunogenicity, which opens a new path in the field of molecular farming for the development of vaccines against atherosclerosis.

\subsection{Ebola}

In their recent work, Bhoo et al. (2011) used a geminiviral replicon system for production of Ebola immune complex (EIC) in Nicotiana benthamiana. Ebola glycoprotein GP1 was fused at the C-terminal end of the heavy chain of humanized 6D8 IgG monoclonal antibody, specifically targeting the linear epitope of GP1. When co-expressed via geminiviral vectors, heavy chain and 6D8 light chain resulted in assembled immunoglobulin. It was purified and its conformation was evaluated by $\mathrm{CC1q}$ binding assay, dynamic light scattering and size exclusion chromatography. When subcutaneously immunized, mice elicited anti-Ebola virus antibodies at levels comparable to those obtained with a GP1 VLP, which is promising for using plant-produced EIC as human vaccines. Recently, a combination of 3 anti-ebola antibodies, called ZMapp, has been expressed in transgenic tobacco by Californian company Mapp Biopharmaceuticals (ISIS ..., 2014). ZMapp, previously tested only in monkeys, was administered to two Americans, infected in Africa, but in the case of the one that survived, it was not sure if that was due to ZMapp or was due to the blood transfusion received before ZMapp. So far no official report on production or function of ZMapp has been released. It is known, however, that the genes for humanized anti-ebola monoclonal antibodies are introduced to plant (tobacco) tissue via plant viral vectors by method of magnifection and that the final yield of $\mathrm{mAb}$ adds up to $1 \%$ of the cytoplasmic protein of tobacco leaf.

\subsection{Anthrax}

Anthrax has recently gained importance due to its potential application as a bio-warfare agent, besides frequent natural outbreaks around the world, especially in Africa, Central Asia and South America. The first research towards producing a plant-based subunit oral vaccine against anthrax was done by Aziz et al. (2002), who expressed protective antigen (PA) in tobacco, transformed by Agrobacterium-mediated transformation method. The PA transgene was found successfully integrated into tobacco nuclear genome and the protein was expressed with a predicted molecular weight of $83 \mathrm{kDa}$. Cytotoxicity assay confirmed

Acta agriculturae Slovenica, 107 - 1, marec 2016 
the retention of its biological activity. CT-Banthrax lethal factor fusion protein was expressed in transgenic potato (Kim et al., 2004b), assembled into oligomeric structures, resembling the native pentamers, its accumulation level being 0.00039 $0.0018 \%$ TSP. This proved the feasibility of edible plants, such as potato, for production of anthrax lethal protein and its theoretical delivery. Recently, Gornatala et al. (2014) expressed protective antigene (PA) in Indian mustard (Agrobacteriummediated transformation) and in tobacco (plastid transformation), under the control of CaMV 35S promoter. Expression level was $0.3-0.8 \%$ TSP in mustard and $2.5-4 \%$ in tobacco. Macrophage lysis assay showed $23-81 \%$ lysis for PA derived from mustard and $80-97 \%$ lysis for PA from tobacco samples. Both oral and intraperitoneal application of either mustard- or tobacco-produced PA resulted in protective immune response with high serum PA-specific IgG or IgA titers in mice. Co-administration of CT-B as an adjuvant by gavage enhanced the response, even when antigen doses were as low as 5 or $10 \mu \mathrm{g}$. PA-specific mucosal immune response was observed in orally immunized mice.

\section{CONCLUSION}

During the last five years a lot of progress has been made in the field of plant-made vaccines. Novel transformation methods and expression vectors have been applied to plant species that had already proven themselves fit for expressing potential vaccine antigens, trying to enhance the expression of transgenes, protein accumulation and stability as well as facilitate the purification process. Obtained increases in accumulation and well-preserved biological function of produced antigens provide a promising basis for future development of plantderived vaccines. Before such vaccines can be produced on industrial scale and broadly accepted, there is still a lot to be done in order to eliminate all possible risks they could pose towards environment and living creatures and gain public acceptance of their usage, however, a lot more research and development of the field can be expected in the following years.

\section{REFERENCES}

Aguirreburualde M. S. P., Gomez M. C., Ostachuk A., Wolman F., Albanesi G., Pecora A., Odeon A., Ardila F., Escribano J. M., Dus Santos M. J., Widgorovitz A. 2013. Efficacy of a BVDV subunit vaccine produced in alfalfa transgenic plants. Veterinary Immunology and Immunopathology, 151: 315-324, doi: 10.1016/j.vetimm.2012.12.004

Arakawa T., Chong D. K. X., Merritt J. L., Langridge W. H. R. 1997. Expression of cholera toxin B subunit oligomers in transgenic potato plants. Transgenic research, 6: 403-413, doi: 10.1023/A:1018487401810

Arakawa T., Yu J., Langridge W. H. R. 2001. Synthesis of a cholera toxin B subunit-rotavirus NSP4 fusion protein in potato. Plant cell reports, 20: 343-348, doi: $10.1007 / \mathrm{s} 002990000312$

Ashraf S., Singh P. K., Yadav D. K., Shahnawaz Md., Mishra S., Sawant S. V., Tuli R. 2005 High level expression of surface glycoprotein of rabies virus in tobacco leaves and its immunoprotective activity in mice. Journal of biotechnology, 119: 1-14, doi: 10.1016/j.jbiotec.2005.06.009

Aziz M. A., Singh S., Kumar A., Bhatnagar R. 2002. Expression of protective antigen in transgenic plants: a step towards edible vaccine against anthrax. Biochemical and biophysical research communications, 299: 345-351, doi: 10.1016/S0006-291X(02)02625-6

Bergeron-Sandoval L.P., Girard A., Ouellet F., Archambault D., Sarhan F. 2011. Production of human rotavirus and Salmonella antigens in plants and elicitation of fljB-specific humoral responses in mice. Molecular biotechnology, 47: 157-168, doi: $10.1007 / \mathrm{s} 12033-010-9324-\mathrm{z}$

Berinstein A., Vazquez-Rovere C., Asurmendi S., Gomez E., Zanetti F., Zabal O., Tozzini A., Conte Grand D., Taboga O., Caamante G., Barrios H., Hoppa E., Carrillo E. 2005. Mucosal and systemic immunization elicited by Newcastle disease virus (NDV) transgenic plants as antigens. Vaccine, 23: 5583-5589, doi: 10.1016/j.vaccine.2005.06.033 
Bertran K., Thomas C., Guo X., Bublot M., Prichard N., Regan J. T., Cox K. M., Gasdaska J. R., Dickey L. F., Kapczynski D. R., Swayne D. E. 2015. Expression of $\mathrm{H} 5$ hemagglutinin vaccine antigen in common duckweed (Lemna minor) protects against $\mathrm{H} 5 \mathrm{~N} 1 \mathrm{high}$ pathogenicity avian influenza virus challenge in immunized chickens. Vaccine, 33: 3456-3462, doi: 10.1016/j.vaccine.2015.05.076

Bhoo S. H., Lai H., Ma J., Arntzen C. J., Chen Q., Mason H. S. 2011. Expression of an immunogenic ebola immune complex in Nicotiana benthamiana. Plant biotechnology, 9, 7: 807-816, doi: 10.1111/j.1467-7652.2011.00593.x

Carillo C., Widgorovitz A., Oliveros J. C., Zamorano P. I., Sadir A. M., Gomez N., Salinas J., Escribano J. M., Borca M. V. 1998. Protective immune response to foot-and-mouth-disease virus with VP1 expressed in transgenic plants. Journal of Virology, 72, 2: 1688-1690

Carolina C, Francisco A.C. 2004. Tomato transformation and transgenic plant production. Plant Cell Tissue Organ Cultivation, 76: 269-275, doi: 10.1023/B:TICU.0000009249.14051.77

Chan H.T., Chia M.Y., Pang V. F., Jeng C.R., Do Y.Y., Huang P.L. 2013. Oral immunogenicity of porcine reproductive and respiratory syndrome virus antigen expressed in transgenic banana. Plant Biotechnology Journal, 11, 3: 315-324, doi: 10.1111/pbi.12015

Chen Y. R., Wang H. 2002. Transforming HBsAg into peanut and detection of its immunogenicity. Biotechnology Letters, 4: 245-250, doi: 10.1016/j.jviromet.2011.02.001

Chen X., Liu J. 2011. Generation and immunogenicity of transgenic potato expressing the GP5 protein of porcine reproductive and respiratory syndrome virus. Journal of Virological Methods, 173, 1: 153158

Chia M.Y., Hsiao S.H., Chan H.T., Do Y.Y., Huang P.L., Chang H.W., Tsai Y.C., Lin C.M., Pang V. F., Jeng C.R. 2010. Immunogenicity of recombinant GP5 protein of porcine reproductive and respiratory syndrome virus expressed in tobacco plant. Veterinary Immunology and Immunopathology, 135, 3-4: 234-242, doi: 10.1016/j.vetimm.2011.01.002

Chia M.Y., Hsiao S.H., Chan H.T., Do Y.Y., Huang P.L., Chang H.W., Tsai Y.C, Lin C.M., Pang V. F., Jeng C.R. 2011. Evaluation of the immunogenicity of a transgenic tobacco plant expressing the recombinant fusion protein of GP5 of porcine reproductive and respiratory syndrome virus and $\mathrm{B}$ subunit of Eschericia coli heat-labile enterotoxin in pigs. Veterinary Immunology and Immunopathology, 140, 3-4: 215-225

Chikwamba R., McMurray J., Shou H., Frame B., Pegg S. E., Scott P., Mason H. S., Wang K. 2002. Expression of a synthetic E. coli heat-labile enterotoxin B subunit (LT-B) in maize. Molecular breeding, $\quad 10$ : 253-265, doi: 10.1023/A:1020509915672

Choi N. W., Estes M. K., Langridge W. H. R. 2005. Synthesis and assembly of a cholera toxin B subunit-rotavirus VP7 fusion protein in transgenic potato. Molecular biotechnology, 31: 193-202, doi: 10.1385/MB:31:3:193

Chung I. S., Kim C. H., Kim I. K., Hong S. H., Park J. H., Kim J. K. Kim W. Y. 2000. Production of recombinant rotavirus VP6 from a suspension culture of transgenic tomato (Lycopersicon esculentum Mill.) cells. Biotechnology letters, 22: 251-255, doi: 10.1023/A:1005626000329

Chung I. S., Kim C. H., Kim I. K., Hong S. H., Lee Y. H. 2001. Improved production of recombinant rotavirus VP6 in sodium butyrate-supplemented suspension cultures of transgenic tomato (Lycopersicon esculentum Mill.) cells. Biotechnology letters, 23: 1061-1066, doi: 10.1023/A:1010525428239

Circelli P., Donini M., Villani M. E., Benvenuto E., Marusic C. 2010. Efficient Agrobacterium-based transientexpression system for the production of biopharmaceuticals in plants. Bioengineered bugs, 1, 3: 221-224, doi: 10.4161/bbug.1.3.11722

Cueno M. E., Hibi Y., Karamatsu K., Yasutomi Y., Imai K., Laurena A. C., Okamoto T. 2010. Preferential expression and immunogenicity of HIV-1 Tat fusion protein expressed in tomato plant. Transgenic research, 19: 889-895, doi: $10.1007 / \mathrm{s} 11248-009-9358-9$

Daniell H., Lee S. B, Panchal T., Wiebe P. O. 2001. Expression of the native cholera toxin subunit $\mathrm{B}$ gene and assembly as functional oligomers in transgenic tobacco chloroplasts. Journal of molecular biology, 311, 5: 1001-1009, doi: 10.1006/jmbi.2001.4921

Dong J. L., Liang B. G., Jin Y. S., Zhang W. J., Wang T. 2005. Oral immunization with pBsVP6transgenic alfalfa protects mice against rotavirus infection. Virology, 339: 153-16, doi: 10.1016/j.virol.2005.06.004

Du G. L., Song C. Z., Zhang G. L., Sun X. G., Liu D. R. 2004. Transgenic Lycium barbarum L. established as HIV capsid protein expression system. Plant molecular biology reporter, 23: 411-416, doi: 10.1007/BF02788889

Acta agriculturae Slovenica, 107 - 1, marec 2016 
Dus Santos M. J., Widgorovitz A., Trono K., Rios R. D., Franzone P. M., Gil F., Moreno J., Carillo, Escribano J. M., Borca M. V. 2002. A novel methodology to develop a foot and mouth disease virus (FMDV) peptide-based vaccine in transgenic plants. Vaccine, 20: 1141-1147, doi: 10.1016/S0264-410X(01)00434-0

Dus Santos M. J., Widgorovitz A. 2005. Transgenic plants for the production of veterinary vaccines. Immunology and Cell Biology, 83: 229- 238, doi: 10.1111/j.1440-1711.2005.01338.x

Dus Santos M. J., Carillo C., Ardila F., Rios R. D., Franzone P., Piccone M. E., Widgorovitz A., Borca M. V. 2005. Development of transgenic alfalfa plants containing the foot and mouth disease virus structural polyprotein gene $\mathrm{P} 1$ and its utilization as an experimental immunogen. Vaccine, 23: 18381843, doi: 10.1016/j.vaccine.2004.11.014

Firsov A., Tarasenko I., Mitiouchkina T., Ismailova N., Shaloiko L., Vainstein A., Dolgov S. 2015. Highyield expression of M2e peptide of avian influenza virus $\mathrm{H} 5 \mathrm{~N} 1$ in transgenic duckweed plants. Molecular biotechnology, 57: 653-661, doi: 10.1007/s12033-015-9855-4

Gao Y., Ma Y., Li M., Cheng T., Li SW, Zhang J., Xia NS. 2003. Oral immunization of animals with transgenic cherry tomatillo expressing HBsAg. World Journal of Gastroenterology, 9, 5: 996-1002, doi: 10.3748/wjg.v9.i5.996

Gomez E., Zoth S. C., Asurmendi S., Vazquez-Rovere C., Berinstein A. 2009. Expression of Hemagglutinin-Neuraminidase glycoprotein of Newcastle Disease Virus in agroinfiltrated Nicotiana benthamiana plants. Journal of biotechnology, 144: 337-340, doi: 10.1016/j.jbiotec.2009.09.015

Gomez-Lim M. A. 2014. Newcastle disease vaccines. In: Commercial plant-produced recombinant protein products. Case studies. J. A. Howard \& E. E. Hood (Eds.), Springer-Verlag Berlin Heidelberg: 189

https://books.google.si/books?id=ZS9nBAAAQBA $\mathrm{J} \& p g=\mathrm{PA} 189 \& \mathrm{lpg}=\mathrm{PA} 189 \& \mathrm{dq}=$ newcastle + disease $+\mathrm{HN}+$ tobacco+suspension+USDA\&source=bl\&ots =wM6aAzBxwo\&sig=zoOpMo3bjfmGDBfNcZqo GvQlXFI\&hl=sl\&sa=X\&ved=0ahUKEwjzzdqzqar KAhXECCwKHUmrCq0Q6AEIJjAB\#v=onepage $\& q=$ newcastle $\% 20$ disease $\% 20 \mathrm{HN} \% 20$ tobacco $\%$ 20 suspension $\% 20 \mathrm{USDA} \& \mathrm{f}=$ false

Gonzales-Rabade N., McGowan E. G., Zhou F., McCabe M. S., Bock R., Dix P. J., Gray J. C., Ma J. K.C. 2011. Immunogenicity of chloroplast-derived HIV-1 p24 and a p24-Nef fusion protein following subcutaneous and oral administration in mice. Plant biotechnology journal, 9: 629-638, doi: 10.1111/j.1467-7652.2011.00609.x

Greco R., Michel M., Guetard D., Cervantes-Gonzales M., Pelucchi N., Wain-Hobson S., Sala F., Sala M. 2008. Production of recombinant HIV-1/HBV virus-like particles in Nicotiana tabacum and Arabidopsis thaliana plants for a bivalent plantbased vaccine. Vaccine, 25, 49: 8228-8240, doi: 10.1016/j.vaccine.2007.09.061

Guan Z. J., Guo B., Huo Y. L., Guan Z. P., Wei Y. H. 2010. Overview of expression of hepatitis B surface antigen in transgenic plants. Vaccine, 28: 73517362, doi: 10.1016/j.vaccine. 2010.08 .100

Guan Z.J., Guo B, Huo Y. L., Guan Z.P., Dai J. K., Wei Y. H. 2013. Recent advances and safety issues of transgenic plant-derived vaccines. Applied microbiology and biotechnology, 97: 2817-2840, $10.1007 / \mathrm{s} 00253-012-4566-2$

Guerrero-Andrade O., Loza-Rubio E., Olivera-Flores T., Fehervari-Bone T., Gomez-Lim M. A. 2006. Expression of the Newcastle disease virus fusion protein in transgenic maize and immunological studies. Transgenic research, 15: 455-463, doi: 10.1007/s11248-006-0017-0

Guetard D., Greco R., Cervantes-Gonzales M., Celli S., Kostrzak A., Langlade-Demoyen P., Sala F., WainHobson S., Sala M. 2008. Immunogenicity and tolerance following $\mathrm{HIV}-1 / \mathrm{HBV}$ plant-based oral vaccine administration. Vaccine, 26: 4477-4485, doi: 10.1016/j.vaccine.2008.06.059

Guo Q.Q., Zhang Z.L., Jiang S.J., Ma J.T., Xue W.T., $\mathrm{Wu}$ Y.M. 2012. Expression of an avian influenza virus (H5N1) hemagglutinin gene in transgenic Lotus corniculatus. Plant molecular biology reporter, 30: 1117-1124, doi: 10.1007/s11105-0120423-9

Hahn B.S., Jeon I.S., Jung Y.J., Kim J.B., Park J.S., Ha S.H., Kim K.H., Kim H.M., Yang J.S., Kim Y.H. 2007. Expression of hemagglutinin-neuraminidase protein of Newcastle disease virus in transgenic tobacco. Plant biotechnology reports, 1: 85-92, doi: $10.1007 / \mathrm{s} 11816-007-0012-9$

Haq T. A., Mason H. S., Clements J. D., Arntzen C. J. 1995. Oral immunization with a recombinant bacterial antigen produced in transgenic plants. Science, 268, 5211: 714-716, doi: $10.1126 /$ science. 7732379

Hayden C. A., Streatfield S. J., Lamphear B. J., Fake G. M., Keener T. K., Walker J. H., Clements J. D., Turner D. D., Tizard I. R., Howard J. A. 2012. Bioencapsulation of the hepatitis B surface antigen 
and its use as an effective oral immunogen. Vaccine, 30: 2937-2942, doi: 10.1016/j.vaccine.2012.02.072

Hayden C. A., Smith E. M., Turner D. D., Keener T. K., Wong J. C., Walker J. H., Tizard I. R., JimenezFlores R., Howard J. A. 2014. Supercritical fluid extraction provides an enhancement to the immune response for orally-delivered hepatitis B surface antigen. Vaccine, 32: 1240-1246, doi: 10.1016/j.vaccine.2014.01.037

Hayden C. A., Fischer M. E., Andrews B. L., Chilton H. C., Turner D. D., Walker J. H., Tizard I. R., Howard J. A. 2015. Oral delivery of wafer made from HBsAg-expressing maize germ induces longterm immunological systemic and mucosal responses. Vaccine, 33: 2881-2886, doi: 10.1016/j.vaccine.2015.04.080

He D.M., Qian K.X., Shen G.F., Li Y.N., Zhang Z.F., Su Z.L., Shao H.B. 2007. Stable expression of footand-mouth disease virus protein VP1 fused with cholera toxin B subunit in the potato (Solanum tuberosum). Colloids and Surfaces B: Biointerfaces, 55: 159-163, doi: 10.1016/j.colsurfb.2006.11.043

Hu J., Ni Y., Dryman B. A., Meng X. J., Zhang C. 2012. Immunogenicity study of plant-made oral subunit vaccine against porcine reproductive and respiratory syndrome virus (PRRSV). Vaccine, 30, 12: 2068- 2074, doi: 10.1016/j.vaccine.2012.01.059

Huang Z., Elkin G. Maloney B. J., Beuhner N., Arntzen C. J., Thanavala Y., Mason H. S. 2005. Virus-like particle expression and assembly in plants: hepatitis B and Norwalk viruses. Vaccine, 23: 1851-1858, doi: 10.1016/j.vaccine.2004.11.017

Huang Z., Chen Q., Hjelm B., Arntzen C. J., Mason H. S. 2009. A DNA replicon system for rapid highlevel production of virus-like particles in plants. Biotechnology bioengineering, 103, 4: 706-714, doi: 10.1002/bit.22299

Huy N.X., Yang M.S., Kim T.G. 2011. Expression of a cholera toxin B subunit-neutralizing epitope of the porcine epidemic diarrhea virus fusion gene in transgenic lettuce (Lactuca sativa L.). Molecular biotechnology, 48: 201-209, doi: 10.1007/s12033010-9359-1

ISIS. 2014. Virus vaccine made in tobacco plants to control ebola, report 26/08/14 http://www.isis.org.uk/Virus_Vaccine_Made_In_T obacco_Plants_to_Control_Ebola.php

Jani D., Meena L. S., Rizwan-ul-Haq Q. M., Singh Y., Sharmal A. K., Tyagi A. K. 2002. Expression of cholera toxin B subunit in transgenic tomato plants. Transgenic research, 11: 447-454, doi: 10.1023/A:1020336332392
Jiang X.L., He Z.M., Peng Z.Q., Qi Y., Chen Q., Yu S.Y. 2007. Cholera toxin B protein in transgenic tomato fruit induces systemic immune response in mice. Transgenic Research, 16: 169-175, doi: 10.1007/s11248-006-9023-5

Kalthoff D., Giritch A., Geisler K., Bettmann U., Klimyuk V., Hehnen H.R., Gleba Y., Beer M. 2010. Immunization with plant-expressed hemagglutinin protects chickens from lethal highly pathogenic avian influenza virus $\mathrm{H} 5 \mathrm{~N} 1$ challenge infection. Journal of virology, 84, 22: 12002-12010, doi: 10.1128/JVI.00940-10

Kang T.J., Han S.C., Kim M.Y., Kim Y.S., Yang M.S. 2004a Expression of non-toxic mutant of Escherichia coli heat-labile enterotoxin in tobacco chloroplasts. Protein expression and purification, 38: 123-128, doi: 10.1016/j.pep.2004.08.002

Kang T.J., Loc N.H., Yang M.O., Yang M.S. 2004b Modification of the cholera toxin B subunit coding sequence to enhance expression in plants. Molecular breeding, 13: 143-153, doi: 10.1023/B:MOLB.0000018762.27841.7a

Kang T.J., Han S.C., Yang M.S., Jang Y.S. 2006a. Expression of synthetic neutralizing epitope of porcine epidemic diarrhea virus fused with synthetic B subunit of Escherichia coli heat-labile enterotoxin in tobacco plants. Protein expression and purification, 46: 16-22, doi: 10.1016/j.pep.2005.07.026

Kang T.J., Lee W-S., Choi E.G. Kim J.W., Kim B.G., Yang M.S. 2006b. Mass production of somatic embryos expressing Escherichia coli heat-labile enterotoxin B subunit in Siberian ginseng. Journal of biotechnology, 121: 124-133, doi: 10.1385/MB:32:2:093

Kang T.J., Kim B.G., Yang J.Y., Yang M.S. 2006c. Expression of a Synthetic Cholera Toxin B Subunit in Tobacco Using Ubiquitin Promoter and bar Gene as a Selectable Marker. Molecular biotechnology, 32: 93-100, doi: 10.1016/j.jbiotec.2005.07.020

Kapusta J., Modelska A., Figlerowicz M., Pniewski T., Letellier M., Lisowa O., Yusibov V., Koprowski H., Plucienniczak A., Legocki A. B. 1999. A plantderived edible vaccine against hepatitis B virus. The FASEB Journal, 13: 1796-1799

Karaman S., Cunnick J., Wang K. 2006. Analysis of immune response in young and aged mice vaccinated with corn-derived antigen against Escherichia coli heat-labile enterotoxin. Molecular biotechnology, 32, $\quad 1$ : 31-42, doi: 10.1385/MB:32:1:031

Karaman S., Cunnick J., Wang K. 2012. Expression of the cholera toxin B subunit (CT-B) in maize seeds

Acta agriculturae Slovenica, 107 - 1, marec 2016 
and a combined mucosal treatment against cholera and traveler's diarrhea. Plant cell reports, 31: 527537, doi: 10.1007/s00299-011-1146-3

Kim T. G., Langridge W. H. R. 2003. Assembly of cholera toxin B subunit full-length rotavirus NSP4 fusion protein oligomers in transgenic potato. Plant cell reports, 21: 884-890

Kim T.G., Langridge W. H.R. 2004a. Synthesis of an HIV-1 Tat transduction domain-rotavirus enterotoxin fusion protein in transgenic potato. Plant cell reports, 22: 382-387, doi: 10.1007/s00299-003-0697-3

Kim T.G., Langridge W. H. R. 2004b. Synthesis and assembly of a cholera toxin B subunit SHIV 89.6p Tat fusion protein in transgenic potato. Protein expression and purification, 35: 313-319, doi: 10.1016/j.pep.2004.02.007

Kim T.G., Ruprecht R., Langridge W. H. R. 2004a. Synthesis and assembly of SIVmac gag p27 capsid protein cholera toxin B subunit fusion protein in transgenic potato. Molecular biotechnology, 28: 3341, doi: 10.1385/MB:28:1:33

Kim T.G., Galloway D. R., Langridge W. H. R. 2004 b. Synthesis and assembly of anthrax lethal factorcholera toxin B-subunit fusion protein in transgenic potato. Molecular biotechnology, 28: 175-183, doi: 10.1385/MB:28:3:175

Kim T.G, Kim M.Y., Kim B.G., Kang T.J., Kim Y.S, Jang Y.S, Arntzen C. J., Yang M.S. 2007. Synthesis and assembly of Escherichia coli heat-labile enterotoxin B subunit in transgenic lettuce (Lactuca sativa). Protein expression and purification, 51:2227, doi: 10.1016/j.pep.2006.05.024

Kim Y.S., Kim M.Y., Kim T.G., Yang M.S. 2009. Expression and Assembly of Cholera Toxin B Subunit (CTB) in transgenic carrot (Daucus carota L.). Molecular biotechnology, 41: 8-14, doi: 10.1007/s12033-008-9086-Z

Kim T.G, Kim M.Y., Yang M.S. 2010. Cholera toxin B subunit-domain III of dengue virus envelope glycoprotein $\mathrm{E}$ fusion protein production in transgenic plants. Protein expression and purification, 74 : 236-241, doi: 10.1016/j.pep.2010.07.013

Lai H., He J., Engle M., Diamond M. S., Chen Q. 2012. Robust production of virus-like particles and monoclonal antibodies with geminiviral replicon vectors in lettuce. Plant biotechnology journal, 10, 1: 95-104, doi: 10.1111/j.1467-7652.2011.00649.x

Lai K. S., Yusoff K., Mahmood M. 2013. Functional ectodomain of the hemagglutinin-neuraminidase protein is expressed in transgenic tobacco cells as a candidate vaccine against Newcastle disease virus. Plant cell, tissue and organ culture, 112: 117-121, doi: 10.1007/s11240-012-0214-x

Landry N., Ward B. J., Trepanier S., Montomoli E., Dargis M., Lapini G., Vezina L-P. 2010. Preclinical and clinical development of plant-made virus-like particle vaccine against avian $\mathrm{H} 5 \mathrm{~N} 1$ influenza. Plos one, 5, 12:1-9, doi: 10.1371/journal.pone.0015559

Lauterslager T. G. M. Florack D. E. A., Van der Wal T. J., Molthoff J. W., Langeveld J. P. M., Bosch D., Boersma W. J. A., Hilgers L. A. Th. 2001. Oral immunisation of naïve and primed animals with transgenic potato tubers expressing LT-B. Vaccine, 19: 2749-2755, doi: 10.1016/S0264$410 \mathrm{X}(00) 00513-2$

Lentz E. M., Mozgovoj M. V., Bellido D., Dus Santos M. J., Wisgorovitz A., Bravo-Almonacid F. F. 2011. VP8* antigen produced in tobacco transplastomic plants confers protection against bovine rotavirus infection in a suckling mouse model. Journal of biotechnology, 156: 100-107, doi: 10.1016/j.jbiotec.2011.08.023

Li D., O’Leary J., Huang Y., Huner N. P. A., Jevnikar A M., Ma S. 2006. Expression of cholera toxin B subunit and the B chain of human insulin as a fusion protein in transgenic tobacco plants. Plant cell reports, 25: 417-424, doi: 10.1007/s00299-0050069-2

Loc N. H., Bach N. H., Kim T.G., Yang M.S. 2010. Tissue culture and expression of Escherichia coli heat-labile enterotoxin B subunit in transgenic Peperomia pellucida. Protein expression and purification, 72 : 82-86, doi: 10.1016/j.pep.2010.02.010

Loc N. H., Bach N. H, Kim T.G., Yang M.S. 2011a. Expression of the Escherichia coli heat-labile enterotoxin B subunit in transgenic watercress (Nasturtium officinale L.). Plant cell tissue and organ culture, 105:39-45, doi. 10.1007/s11240010-9835-0

Loc N. H., Thinh L. T., Yang M.S., Kim T.G. 2011 b. Highly expressed cholera toxin B subunit in the fruit of a transgenic tomato (Lycopersicon esculentum L.). Biotechnology and bioprocess engineering, 16: 576-580

Loc N. H., Long D. T., Kim T.G., Yang M.S. 2014. Expression of Escherichia coli heat-labile enterotoxin B subunit in transgenic tomato (Solanum lycopersicum L.) fruit. Czech journal of genetics and plant breeding, 50, 1: 26-31

Lombardi R., Circelli P., Villani M. E., Buriani G., Nardi L., Coppola V., Bianco L., Benvenuto E., 
Donini M., Marusic C. 2009. High-level HIV-1 Nef transient expression in Nicotiana benthamiana using the P19 gene silencing suppressor protein of Artichoke

Lou X.M, Zhang Z., Xiong A.S, Wang HK, Peng R.H, Li X. 2005. Hepatitis B surface antigen protein (S1S2) gene expression in transgenic apples. Journal of Fruit Science, 22, 6: 601-610

Loza-Rubio E., Rojas-Anaya E., Lopez J., OliveraFlores M. T., Gomez-Lim M., Tapia-Perez G. 2012. Induction of a protective immune response to rabies virus in sheep after oral immunization with transgenic maize, expressing the rabies virus glycoprotein. Vaccine, 30: 5551-5556, doi: 10.1016/j.vaccine.2012.06.039

Ma Y., Lin SQ, Gao Y., Zhang J., Lu LX, Xia NS. 2002. Transformation of HBsAg (hepatitis B virus surface antigen) into tomato plants. J Fuijan Agric Forest Univ (Nat Sci Ed), 31: 223-228

Martinez-Gonzales L., Rosales-Mendoza S., SoriaGuerra R. E., Moreno-Fierros L., Lopez-Revilla R., Korban S. S., Guevara-Arauza J. C., Alpuche-Solis A. G. 2011. Oral immunization with a lettucederived Escherichia coli heat-labile toxin B subunit induces neutralizing antibodies in mice. Plant cell tissue and organ culture, 107: 441-449, doi: 10.1007/s11240-011-9994-7

Marusic C., Nuttall J., Buriani G., Lico C., Lombardi R., Baschieri S., Benvenuto E., Frigerio L. 2007. Expression, intracellular targeting and purification of HIV Nef variants in tobacco cells. BMC Biotechnology, 7, 12: 1-12

Mason H. S., Lam D. M.K., Arntzen C. J. 1992. Expression of hepatitis B surface antigen in transgenic plants. Proceedings of the National Academy of Sciences of the United States of America, 89: 11745-11749, doi: 10.1073/pnas.89.24.11745

Mason H. S., Ball J. M., Shi J.J., Jiang X., Estes M. K. Arntzen C. J. 1996. Expression of Norwalk virus capsid protein in transgenic tobacco and potato and its oral immunogenicity in mice. Proceedings of the national academy of sciences of the United States of America, 93: 5335-5340, doi: 10.1073/pnas.93.11.5335

Mason H. S., Haq T. A., Clements J. D., Arntzen C. J. 1998. Edible vaccine protects mice against Escherichia coli heat-labile enterotoxin (LT): potatoes expressing a synthetic LT-B gene. Vaccine, 16, 13: 1336-1343, doi: 10.1016/S0264410X(98)80020-0

Matsumura T., Itchonda N., Tsunemitsu H. 2002. Production of immunogenic VP6 protein of bovine group A rotavirus in transgenic potato plants. Archieves of virology, 147: 1263-1270

McGarvey P. B., Hammond J., Dienelt M. M., Hooper D. C., Fu Z. F., Dietzschold B., Koprowski H., Michaels F. H. 1995. Expression of the rabies virus glycoprotein in transgenic tomatoes. Biotechnology, 13: 1484-1487, doi: $10.1038 /$ nbt1295-1484

Meyers A., Chakuya E., Shephard E., Tanzer F. L., Maclean J., Lynch A., Williamson A.L., Rybicki E. P. 2008. Expression of HIV-1 antigens in plants as potential subunit vaccines. BMC Biotechnology, 8 , 53: 1-15, doi: 10.1186/1472-6750-8-53

Mikschofsky H., Konig P., Keil G. M., Hammer M., Schirrmeier H., Broer I. 2009. Cholera toxin B (CTB) is functional as an adjuvant for cytoplasmatic proteins if directed to the endoplasmatic reticulum (ER), but not to the cytoplasm of plants. Plant science, 177: 35-42, doi: 10.1016/j.plantsci.2009.03.010

Mishra S., Yadav D. K., Tuli R. 2006. Ubiquitin fusion enhances cholera toxin $\mathrm{B}$ subunit expression in transgenic plants and the plant-expressed protein binds GM1 receptors more efficiently. Journal of biotechnology, 127: 95-108, doi: 10.1016/j.jbiotec.2006.06.002

Modelska A., Dietzschold B., Sleysh N., Fu Z. F., Steplewski K., Hooper D. C., Koprowski H, Yusibov V. 1998. Immunization against rabies with plant-derived antigen. Proceedings of the national academy of science, 95: 2481-2485, doi: 10.1073/pnas.95.5.2481

Moravec T., Schmidt M. A., Herman E. M., WoodfordThomas T. 2007. Production of Escherichia coli heat labile toxin (LT) B subunit in soybean seed and analysis of its immunogenicity as an oral vaccine. Vaccine, 25: 1647-1657, doi: 10.1016/j.vaccine.2006.11.010

Nelson G., Marconi P., Periolo O., La Torre J., Alvarez M. A. 2012. Immunocompetent truncated E2 glycoprotein of bovine viral diarrhea virus (BVDV) expressed in Nicotiana tabacum plants: A candidate antigen for new generation of veterinary vaccines. Vaccine, 30: 4499- 4504, doi: 10.1016/j.vaccine.2012.04.068

Pan L., Zhang Y., Wang Y., Wang B., Wang W., Fang Y., Jiang S., Lv J., Wang W., Sun Y., Xie Q. 2008. Foliar extracts from transgenic tomato plants expressing the structural polyprotein, P1-2A, and protease, 3C, from foot-and-mouth disease virus elicit a protective response in guinea pigs. Veterinary Immunology and Immunopathology, 121: 83-90, doi: 10.1016/j.vetimm.2007.08.010

Acta agriculturae Slovenica, 107 - 1, marec 2016 
Pera F. F. P. G., Mutepfa D. L. R., Khan A. M., Els J. H., Mbewana S., Van Dijk A. A. A., Rybicki E. P., Hitzeroth I. I. 2015. Engineering and expression of a human rotavirus candidate vaccine in Nicotiana benthamiana. Virology journal, 12, 205: 1-11, doi: 10.1186/s12985-015-0436-8

Perea Arango I., Loza-Rubio E., Rojas-Anaya E., Olivera-Flores T., De la Vara L. G., Gomez-Lim M. A. 2008. Expression of the rabies virus nucleoprotein in plants at high-levels and evaluation of immune responses in mice. Plant cell reports, 27: 677-685, doi: 10.1007/s00299-0070324-9

Perez-Filgueira D. M., Mozgovoj M., Widgorovitz A., Dus Santos M. J., Parreno V., Trono K., Fernandez F. M., Carrillo C., Babiuk L. A., Morris T. J., Borca M. V. 2004a. Passive protection to bovine rotavirus (BRV) infection induced by a BRV VP8* produced in plants using a TMV-based vector. Archives of virology, 149: 2337-2348, doi: 10.1007/s00705004-0379-7

Perez-Filgueira D. M., Brayfield B. P., Phiri S., Borca M. V., Wood C., Morris T. J. 2004b. Preserved antigenicity of HIV-1 p24 produced and purified in high yields from plants inoculated with a tobacco mosaic virus (TMV)-derived vector. Journal of virological methods, 121: 201-208, doi: 10.1016/j.jviromet.2004.06.022

Piron R., De Koker S., De Paepe A., Goossens J., Grooten J., Nauwynck H., Depicker A. 2014. Boosting In Planta Production of Antigens Derived from the Porcine Reproductive in Respiratory Syndrome Virus (PRRSV) and Subsequent Evaluation of Their Immunogenicity. PLOS ONE, 9, 3: 1-16, doi: 10.1371/journal.pone.0091386

Pniewski T., Kapusta J., Bociag P., Wojciechowicz J., Kostrzak A., Gdula M., Fedorowicz-Stronska O., Wojcik P., Otta H., Samardakiewicz S., Wolko B., PŁucienniczak A. 2011. Low-dose oral immunization with lyophilized tissue of herbicideresistant lettuce expressing hepatitis B surface antigen for prototype plant-derived vaccine tablet formulation. Journal of applied genetics, 107: $441-$ 449, doi: 10.1007/s13353-010-0001-5

Rattanapisit K., Bhoo S. H., Hahn T. R., Mason H. S., Phoolcharoen W. 2013. Rapid transient expression of cholera toxin B subunit (CTB) in Nicotiana benthamiana. In vitro cellular and developmental biology- plant, 49: 107-113, doi: 10.1007/s11627012-9484-6

Ravin N. V., Kotlyarov R. Y., Mardanova E. S., Kuprianov V. V., Migunov A. I., Stepanova L. A., Tsybalova L. M., Kiselev O. I., Skryabin K. G.
2012. Plant-produced recombinant influenza vaccine based on virus-like HBc particles carrying an extracellular domain of M2 protein. Biokhimiya, 77, 1: 43-52, doi: 10.1134/s000629791201004x

Renukaradhya G. J., Meng X-J., Calvert J. G., Roof M., Lager K. M. 2015. Inactivated and subunit vaccines against porcine reproductive and respiratory syndrome: current status and future direction. Vaccine, 33, 27: 3065- 3072, doi: 10.1016/j.vaccine.2015.04.102

Rojas-Anaya E., Loza-Rubio E., Olivera-Flores M. T., Gomez-Lim M. 2009. Expression of rabies virus G protein in carrots (Daucus carota). Transgenic research, 18: 911-919, doi: 10.1007/s11248-0099278-8

Rosales-Mendoza S., Soria-Guerra R. E., Olivera-Flores M. T., Lopez-Revilla R., Arguello-Astroga G. R., Jimenez-Bremont J. F., Garcia-de la Cruz R. F., Loyola-Rodriguez J. P., Alpuche-Solis A. G. 2007. Expression of Escherichia coli heat-labile enterotoxin b subunit (LTB) in carrot (Daucus carota L.). Plant Cell Reports, 26: 969-976, doi: 10.1007/s00299-007-0310-2

Rosales-Mendoza S., Soria-Guerra R. E., Lopez-Revilla R., Moreno-Fierros L., Alpuche-Solis A. G. 2008. Ingestion of transgenic carrots expressing the Escherichia coli heat-labile enterotoxin B subunit protects mice against cholera toxin challenge. Plant Cell Reports, 27: 79-84, doi: 10.1007/s00299-0070439-z

Rosales-Mendoza S. 2015. Current developments and future prospects for plant-made biopharmaceuticals against rabies. Molecular biotechnology, 57: 869879, doi: 10.1007/s12033-015-9880-3

Roy S., Tyagi A., Tiwari S., Singh A., Sawant S. V., Singh P. K., Tuli R. 2010. Rabies glycoprotein fused with B subunit of cholera toxin expressed in tobacco plants folds into biologically active pentameric protein. Protein expression and purification, $\quad 70$ : 184-190, doi: 10.1016/j.pep.2009.10.002

Rukavtsova E. B., Rudenko N. V., Puchko E. N., Zakharchenko N. S., Buryanov Y. I. 2015. Study of the immunogenicity of hepatitis B surface antigen synthesized in transgenic potato plants with increased biosafety. Journal of Biotechnology, 203: 84-88, doi: 10.1016/j.jbiotec.2015.03.019

Salazar-Gonzales J. A., Rosales-Mendoza S. 2013. A perspective for artherosclerosis vaccination: is there a place for plant-based vaccines? Vaccine, 31: 1364-1369, doi: 10.1016/j.vaccine.2013.01.005 
Salazar-Gonzales J. A., Rosales-Mendoza S., RomeroMaldonado A., Monreal-Escalante E., UrestiRivera E. E., Banuelos-Hernandez B. 2014. Production of a plant-derived immunogenic protein targeting ApoB100 and CETP: toward a plantbased artherosclerosis vaccine. Molecular biotechnology, 56: 1133-1142, doi: 10.1007/s12033-014-9793-6

Santi L., Batchelor L., Huang Z., Hjelm B., Kilbourne J., Arntzen C. J., Chen Q., Mason H. S. 2008. An efficient plant viral expression system generating orally immunogenic Norwalk viral-like particles. Vaccine, 26: 1846-1854, doi: 10.1016/j.vaccine.2008.01.053

Scotti N., Alagna F., Ferraiolo E., Formisano G., Sannino L., Buonaguro L., De Stradis A., Vitale A., Monti L., Grillo S., Buonaguro F. M., Cardi T. 2009. High-level expression of the HIV-1 Pr55gag polyprotein in transgenic tobacco chloroplasts. Planta, 229: 1109-1122, doi: 10.1007/s00425-0090898-2

Sharma M. K., Jangi D., Thungapathra M., Gautam J. K., Meena L. S., Singh Y., Ghosh A., Tyagi A. K., Sharma A. K. 2008. Expression of accessory colonization factor subunit A (ACFA) of Vibrio cholerae and ACFA fused to cholera toxin B subunit in transgenic tomato (Solanum lycopersicum). Journal of biotechnology, 135: 2227, doi: 10.1016/j.jbiotec.2008.03.002

Shekhawat U. K. S., Ganapathi T. R., Srinivas L. 2010. Expression of hepatitis B small surface antigen in Santalum album embryogenic cell suspension cultures. Biologia plantarum, 54, 4: 720-724, doi: 10.1007/s10535-010-0128-6

Shoji Y., Farrance C. E., Bi H., Shaloul M., Green B., Manceva S., Rhee A., Ugulava N., Roy G. Musivchuk K., Chichester J. A., Mett V., Yusibov V. 2009. Immunogenicity of hemagglutinin from A/Bar-headed Goose/Qinghai/1A/05 and $\mathrm{A} /$ Anhui/1/05 strains of $\mathrm{H} 5 \mathrm{~N} 1$ influenza viruses produced in Nicotiana benthamiana plants. Vaccine, 27: 3467-3470, doi: 10.1016/j.vaccine.2009.01.051

Shulga N. Y., Rukavtsova, E. B. Krymsky M. A., Borisova V. N., Melnikov V. A., Byrkov V. A. 2004. Expression and characterization of hepatitis B surface antigen in transgenic potato plants. Biochemistry (Mosc), 69:1158-1164, doi: 10.1023/B:BIRY.0000046891.46282.c8

Singh A., Srivastava S., Chouskey A., Panwar B. S., Verma P. C., Roy S. Singh P. K., Saxena G. Tuli R. 2015. Expression of rabies glycoprotein and ricin toxin B chain (RGP-RTB) fusion protein in tomato hairy roots: a step towards oral vaccination for rabies. Molecular biotechnology, 57: 359-370, doi: 10.1007/s12033-014-9829-y

Smith M. L., Mason H. S., Shuler M. L. 2002. Hepatitis surface (HBsAg) expression in plant cell culture: kinetics of antigen accumulation in batch culture and its intracellular form. Biotechnology and Bioengineering, 80: 812-822, doi: 10.1002/bit.10444

Soh H. S., Chung H. Y., Lee H. H., Ajjappala H., Jang K., Par J.H., Sim J.S., Lee G. Y., Lee H. J., Han Y. H., Lim J. W., Choi I., Chung I. S., Hahn B.S. 2015. Expression and functional validation of heatlabile enterotoxin B (LTB) and cholera toxin B (CTB) subunits in transgenic rice (Oryza sativa). Springerplus, 4, 148: 1-14, doi: 10.1186/s40064015-0847-4

Souza A. C., Vasques R. M., Ingone-Nagata A. K., Lacorte C., Madaner F. R., Ferreira Noronha E., Nagata T. 2013. Expression and assembly of Norwalk virus-like particles in plants using a viral RNA silencing suppressor gene. Applied microbiology and biotechnology, 97: 9021-9027, doi: 10.1007/s00253-013-5077-5

Srinivas L., Sunil-Kumar G. B., Ganapathi T. R., Revathi C. J., Bapat V. A. 2008. Transient and stable expression of hepatitis B surface antigen in tomato (Lyopersicon esculentum L.). Plant biotechnology reports, 2: 1-6, doi: 10.1007/s11816008-0041-z

Starodubova E. S., Preobrazhenskaia O. V., Kuzmenko Y. V., Latanova A. A., Yarygina E. I., Karpov V. L. 2015. Rabies Vaccines: Current Status and Prospects for Development. Molecular biotechnology, 49, 4: 513-519, doi: $10.1134 / \mathrm{s} 0026893315040172$

Streatfield S. J., Jilka J. M., Hood E. E., Turner D. D., Bailey M. R., Mayor J. M., Woodard S. L., Beifuss K. K., Horn M. E., Delaney D. E., Tizard I. R., Howard J. A. 2001. Plant-based vaccines: unique advantages. Vaccine, 19: 2742-2748, doi: 10.1016/S0264-410X(00)00512-0

Sunil-Kumar G. B., Ganapathi T. R., Revathi C. J., Srinivas L., Bapat V. A. 2005. Expression of hepatitis B surface antigen in transgenic banana plants. Planta, 222: 484-493, doi: 10.1007/s00425005-1556-y

Sunil-Kumar G. B., Ganapathi T. R., Revathi C. J., Srinivas L., Bapat V. A. 2007. Hepatitis B surface antigen expression in NT-1 cells of tobacco using different expression cassettes. Biologia Plantarium, 51, 3: 467-471, doi: 10.1007/s10535-007-0098-5

Tacket C. O., Mason H. S., Losonsky G., Clements J. D., Levine M. M., Arntzen C. J. 1998.

Acta agriculturae Slovenica, 107 - 1, marec 2016 
Immunogenicity in humans of a recombinant bacterial antigen delivered in transgenic potato. Nature, 4, 5: 607 - 609, doi: 10.1038/nm0598-607

Tacket C. O., Mason H. S., Losonsky G. Estes M. K., Levine M. M., Arntzen C. J. 2000. Human immune responses to a novel Norwalk virus vaccine delivered in transgenic potatoes. The journal of infectious diseases, 182: 302-305, doi: $10.1086 / 315653$

Tacket C. O., Pasetti M. F., Edelman R., Howard J. A., Streatfield S. 2004. Immunogenicity of recombinant LT-B delivered orally to humans in transgenic corn. Vaccine, 22: 4385-4389, doi: 10.1016/j.vaccine. 2004.01 .073

Tang W., Page M. 2013. Inducible expression of Norwalk virus capsid protein gene in plant cell suspension cultures. In vitro cellular and developmental biology- plant, 49: 129-136, doi: $10.1007 / \mathrm{s} 11627-012-9487-3$

Tarasenko I. V., Taranov A. I., Firsov A. P., Dolgov S. V. 2013. Expression of the nucleotide sequence for the M2e peptide of avian influenza virus in transgenic tobacco plants. Applied biochemistry and microbiology, 49, 8: 695-701, doi: $10.1134 / \mathrm{S} 0003683813080061$

Thanavala Y., Mahoney M., Pal S., Scott A., Richter L., Natarajan N., Goodwin P., Arntzen C. J., Mason H. S. 2005. Immunogenicity in humans of an edible vaccine for hepatitis B. PNAS, 102, 9: 3378-3382, doi: 10.1073/pnas.0409899102

Tiwari S., Mishra D. K., Roy S., Singh A., Singh P. K., Tuli R. 2009. High level expression of a functionally active cholera toxin $\mathrm{B}$ : rabies glycoprotein fusion protein in tobacco seeds. Plant cell reports, 28: 1827-1836, doi: 10.1007/s00299009-0782-3

Unni S. C., Soniya E. V. 2010. Transgenic Cucumis sativus expressing the hepatitis B surface antigen. Plant molecular biology reporter, 28: 627-634, doi: 10.1007/s11105-010-0179-Z

Uribe-Campero L., Monroy-García A., Durán-Meza A. L., Villagrana-Escareño M. V., Ruíz-García J., Hernández J., Núñez-Palenius H. G., Gómez-Lim M.A. 2015. Plant-based porcine reproductive and respiratory syndrome virus VLPs induce an immune response in mice. Research in Veterinary Science, 102: 59- 66, doi: 10.1016/j.rvsc.2015.07.012

USDA issues license for plant cell produced Newcastle disease vaccine for chickens. 2006 http://www.thepoultrysite.com/poultrynews/8949/u sda-issues-license-for-plant-cell-producednewcastle-disease-vaccine-for-chickens/

Wagner B., Hufnagl K., Radauer C., Wagner S., Baier K., Scheiner O., Wiedermann U., Breiteneder H. 2004. Expression of the B subunit of the heat-labile enterotoxin of Escherichia coli in tobacco mosaic virus-infected Nicotiana benthamiana plants and its characterization as mucosal immunogen and adjuvant. Journal of immunological methods, 287: 203-215, doi: 10.1016/j.jim.2004.02.001

Wang X.G., Zhang G.H., Liu C.X., Zhang Y.H., Xiao C.Z., Fang R.X. 2001. Purified cholera toxin B subunit from transgenic tobacco plants possesses authentic antigenicity. Biotechnology and bioengineering, 72: 490-494, doi: 10.1002/10970290(20010220)72:4<490::AID-

BIT1011>3.0.CO;2-0

Wang YQ, Li T. 2008. Transformation of HBsAg into tomato and production of transgenic tomato plants. J Southwest Univ (Nat Sci Ed), 30: 78-83

Ward B. J., Landry N., Trepanier S., Mercier G., Dargis M., Couture M., D’Aoust M. A., Vezina L. P. 2014. Human antibody response to N-glycans present on plant-made influenza virus-like particle (VLP) vaccines. Vaccine, 32: 6098-6106, doi: 10.1016/j.vaccine.2014.08.079

Widgorovitz A., Carillo C., Dus Santos M. J., Trono K., Peralta A., Gomez M. C., Rios R. D., Franzone P. M., Sadir A. M., Escribano J. M., Borca M. V. 1999. Induction of a protective antibody response to foot and mouth disease virus in mice following oral or parenteral immunization with alfalfa transgenic plants expressing the viral structural protein VP1. Virology, 255: 347-353, doi: 10.1006/viro.1998.9590

Wu Y.Z., Li J.T., Mou Z.R., Fei L., Ni B., Geng M., Jia Z.C., Zhou W., Zou L.Y., Tang Y. 2003. Oral immunization with rotavirus VP7 expressed in transgenic potatoes induced high titers of mucosal neutralizing IgA. Virology, 31: 337- 342, doi: 10.1016/S0042-6822(03)00280-0

Yang Y.M., Lia X., Yang H., Qian Y., Zhang Y., Fang R.X., Chen X.Y. 2011. Immunogenicity and viruslike particle formation of rotavirus capsid proteins produced in transgenic plants. Science china life sciences, 54, 1: 82-89, doi: 10.1007/s11427-0104104-3

Yang Z.Q., Liu Q.Q., Pan Z.M., Yu H.X. Jiao X.A. 2007. Expression of the fusion glycoprotein of Newcastle disease virus in transgenic rice and its immunogenicity in mice. Vaccine, 25: 591-598, doi: 10.1016/j.vaccine.2006.08.016 
Yu J., Langridge W. H. R. 2001. A plant-based multicomponent vaccine protects mice from enteric diseases. Nature biotechnology, 19: 548-552, doi: $10.1038 / 89297$

$\mathrm{Yu}$ J., Langridge W. 2003. Expression of rotavirus capsid protein VP6 in transgenic potato and its oral immunogenicity in mice. Transgenic research, 12: 163-169, doi: 10.1023/A:1022912130286

Yusibov V., Modelska A., Steplewski K., Agadjanyan M., Weiner D., Hooper D. C., Koprowski H. 1997. Antigens produced in plants by infection with chimeric plant viruses immunize against rabies virus and HIV-1. Proceedings of the national academy of science, 94: 5784-5788, doi: 10.1073/pnas.94.11.5784

Yusibov V., Hooper D. C., Spitsin S. V., Fleysh N., Kean R. B., Mikheva T., Deka D., Karasev A., Cox S. Randall J., Koprowski H. 2002. Expression in plants and immunogenicity of plant virus-based experimental rabies vaccine. Vaccine, 20: 31553164, doi: 10.1016/S0264-410X(02)00260-8
Zhang G. G., Rodrigues L., Rovinski B., White K. A. 2002. Production of HIV-1 p24 Protein in Transgenic Tobacco Plants. Molecular biotechnology, 20: 131-136, doi: 10.1385/MB:20:2:131

Zhang S.Z., Zhang G.L., Rong T.Z., Pan L., Zhou P., Zhang Y.G. 2011. Transformation of two VP1 genes of $\mathrm{O}$ - and Asia 1-type foot-and-mouth disease virus into maize. Agricultural Sciences in China, 10, 5: 661-667, doi: 10.1016/S16712927(11)60048-5

Zhao X. Y., Zhang X. D., Zhang T. 2002. Cloning and expression of hepatitis $\mathrm{B}$ virus surface antigen in carrots. Progress in Microbiology and Immunology, 30, $1: 1$

Zhou B., Zhang Y., Wang X. Dong J., Wang B., Han C., Yu J., Li D. 2010. Oral administration of plantbased rotavirus VP6 induces antigen-specific IgAs, IgGs and passive protection in mice. Vaccine, 28: 6021-6027, doi: 10.1016/j.vaccine.2010.06.094 